\title{
How Many Wild Edible Plants Do We Eat-Their Diversity, Use, and Implications for Sustainable Food System: An Exploratory Analysis in India
}

\section{OPEN ACCESS}

Edited by:

Kathleen L. Hefferon,

Cornell University, United States

Reviewed by:

Chunlin Long,

Minzu University of China, China

Indra Dutt Bhatt,

Govind Ballabh Pant National Institute

of Himalayan Environment and

Sustainable Development, India

Lukasz Luczaj,

University of Rzeszow, Poland

${ }^{*}$ Correspondence:

Avik Ray

avikray@ceibatrust.org

TORCID:

Avik Ray

orcid.org/0000-0003-1662-7679

Specialty section:

This article was submitted to Nutrition and Sustainable Diets,

a section of the journal

Frontiers in Sustainable Food Systems

Received: 23 September 2019

Accepted: 09 April 2020

Published: 11 June 2020

Citation:

Ray A, Ray R and Sreevidya EA (2020)

How Many Wild Edible Plants Do We

Eat-Their Diversity, Use, and

Implications for Sustainable Food

System: An Exploratory Analysis in

India. Front. Sustain. Food Syst. 4:56.

doi: 10.3389/fsufs.2020.00056

\author{
Avik Ray ${ }^{\star \dagger}$, Rajasri Ray and Sreevidya E. A. \\ Center for studies in Ethnobiology, Biodiversity, and sustainability (CEiBa), Malda, India
}

Wild edible plants are still eaten by a large section of the global population and ensure both affordable food and nutritional security. We tested this in an Indian context, where an enormous diversity of such plants constitutes a significant part of the rural diet and their acceptance has been high. In this study, we assessed the diversity of wild edible plant resource and the importance of species based on the use and its pattern. We have also shortlisted a set of plants to make an informed decision on prioritization. We found a great variety of plants (1,403 species) from 184 families were consumed across India, although the first 44 families (24\%) contributed largely to the (75\%) diversity. Leguminosae followed by Compositae, Poaceae, Malvaceae, and Rosaceae, were the families with the highest number of species. We note that a few species from the large pool were extensively used throughout the country while another few were valued for their multiple edible plant parts. Leafy shoots (722 species) followed by fruits (652 species) were the two most-eaten plant parts. Our results strengthen the fact that: (a) wild edibles have been an integral part of the diet; (b) their widespread assimilation into local food culture suggests an untapped potential to ensure easy availability and access to micronutrients for sustainable food systems, and thus in social welfare; and (c) they should be incorporated into the national food policy for formal cultivation and promotion.

Keywords: wild uncultivated plants, edible flora, sustainability, food system, hidden hunger, micronutrient, leafy greens, nutritional security

\section{INTRODUCTION}

Food has been central to human biological and socio-cultural existence, providing energy and nutrition. Sourcing food from the wild had been closely entangled with humanity for millions of years (Gosden and Hather, 2004). It allowed humans to develop an intricate knowledge base about the environment and provided them with a diverse collection of animal and plant derived foods, procured through numerous ingenious ways (Anderson et al., 2011; Chevalier et al., 2014a; Harris and Hillman, 2014). Today, nearly thirty domesticated species comprise a significant portion of dietary diversity and only three principal cereal grains (rice, wheat, and maize) contribute to more than half of the world's calorie intake (FAO, 2010). Thousands of edible species remained wild or semi-wild, and were left-out in the course of domestication; however, these underutilized edible 
floral elements hold the potential to transform our food systems toward being more nutritious, sustainable, and resilient to climate change (Hunter and Fanzo, 2013; Powell et al., 2015). A diverse range of wild uncultivated plants and their parts (e.g., leafy shoots, fruits, seeds, underground organs, and flowers) are still being consumed regularly and complement human adaptability and a variety of human gastronomic choice. They tend to supplement proteins, essential minerals, micronutrients, and vitamins that enrich dietary quality (Ogle, 2001) and thus provide an affordable source of nutrition for rural and semiurban societies across cultures and continents (Rowland et al., 2016; Jones, 2017). Diverse diets have largely been recommended for optimum human nutrition, good health, and overall wellbeing (FAO et al., 2012). While poor quality staple-centric diets lacking diversity may represent the diets of most lowincome households in low- and middle-income countries (Jones, 2017), the acceptance and use of wild food is vibrantly alive to this day, especially in remote economically impoverished corners of the world (Christiensen, 2002; Lykke et al., 2002; Paumgarten and Shackleton, 2011; Cruz-Garcia and Price, 2012; Angelsen et al., 2014; Wunder et al., 2014; Ickowitz et al., 2016). However, the exponential growth of industrial agriculture, rapid urbanization, and the dwindling of forest and semi-forest lands have heavily affected the food system (Padoch and Sunderland, 2014; Broegaard et al., 2017; Ickowitz et al., 2019). The obvious consequences are the decimation of wild populations and loss of the knowledge system required to harvest and process these foods, which eventually led to food system homogenization, micronutrient deficiency, undernourishment, and over-nutrition manifesting in overweight or obesity (Pretty, 1995; Labadarios, 2005; Pinstrup-Andersen, 2007; Pingali, 2015).

The culture of consumption of wild edible plants (henceforth WEP) as food and medicine has been widely exercised by the tribal groups and non-tribal communities living in rural

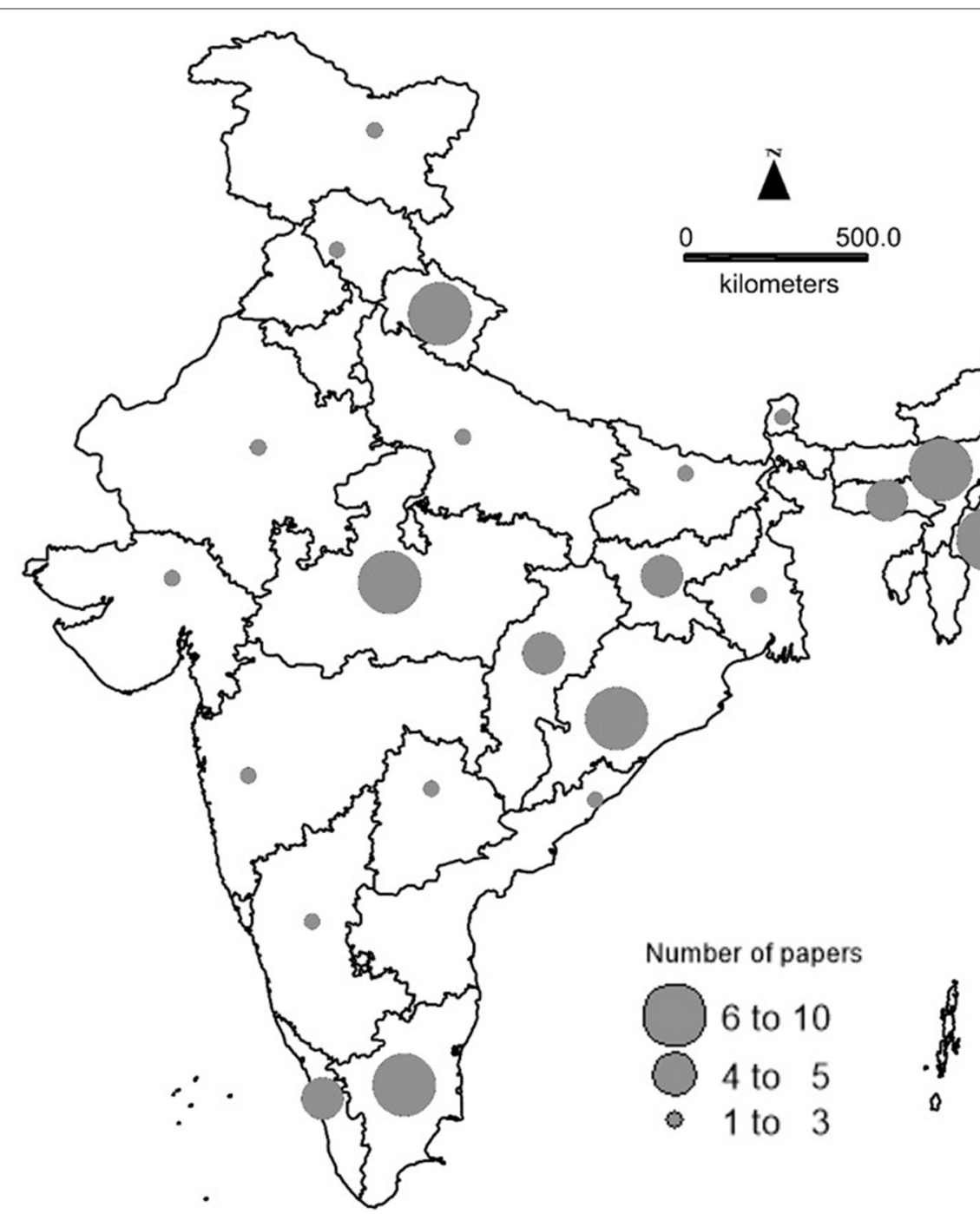

FIGURE 1 | Spatial locations of published articles considered in the current study (circle size is proportional to the number of studies reported from a state). 
TABLE 1 | The list of studies and their broadly studied region.

\begin{tabular}{|c|c|}
\hline References & Broad region \\
\hline Agrahar-Murugkar and Subbulakshmi (2005) & North-east \\
\hline Ajesh et al. (2012) & South \\
\hline Angami et al. (2006) & North-east \\
\hline Arinathan et al. (2007) & South \\
\hline Ayyanar and Ignacimuthu (2005) & South \\
\hline Barua and Tomar (2014) & Central \\
\hline Bedi (1978) & West \\
\hline Behera et al. (2008) & East \\
\hline Bhatt et al. (2005) & North-east \\
\hline Binu (2010) & South \\
\hline Biswas and Das (2011) & East \\
\hline Chaithanya et al. (2015) & South \\
\hline Chand et al. (2017) & North \\
\hline Chauhan et al. (2014) & Central \\
\hline Chauhan et al. (2018) & West \\
\hline Chorol et al. (2018) & North \\
\hline Choudhary et al. (2008) & West \\
\hline Cruz-García (2006) & South \\
\hline Devi et al. (2010) & North-east \\
\hline Devi et al. (2014) & North-east \\
\hline Devi and Salam (2016) & North-east \\
\hline Fatma and Pan (2012) & East \\
\hline Gangte et al. (2013) & North-east \\
\hline Ghatapanadi et al. (2011) & South \\
\hline Ghosh-Jerath et al. (2015) & East \\
\hline Ghosh-Jerath et al. (2016) & East \\
\hline Horo and Topno (2015) & East \\
\hline Ignacimuthu and Ayyanar (2006) & South \\
\hline Jain and Tiwari (2012) & Central \\
\hline Jain et al. (2011) & North-east \\
\hline Jain et al. (2012) & North-east \\
\hline Jain (1964) & Central \\
\hline Jeeva (2009) & North-east \\
\hline Kar (2004) & North-east \\
\hline Kar and Borthakur (2007) & North-east \\
\hline Kar and Borthakur (2008) & North-east \\
\hline Katewa et al. (2003) & West \\
\hline Khan and Kakde (2014) & South \\
\hline Khaund and Joshi (2013) & North-east \\
\hline Konsam et al. (2016) & North-east \\
\hline Kumar (2013) & North \\
\hline Kumar and Shiddamallayya (2014) & South \\
\hline Kumar and Jain (2002) & Central \\
\hline Mahapatra and Panda (2012) & East \\
\hline Maikhuri et al. (1994) & North \\
\hline Mao et al. (2009) & North-east \\
\hline Medhi and Borthakur (2012) & North-east \\
\hline Medhi et al. (2014) & North-east \\
\hline Mishra et al. (2016) & East \\
\hline Mishra and Shrivastava (2015) & Central \\
\hline Misra et al. (2013) & East \\
\hline
\end{tabular}

(Continued)
TABLE 1 | Continued

References

Misra et al. (2008)

Mohammed et al. (2004)

Mukherjee and Chaturvedi (2016)

Murugan et al. (2010)

Nair and Agrawal (2017)

Namsa et al. (2011)

Nath and Maiti (2011)

Neogi et al. (1989)

Nongdam and Tikendra (2014)

Narayanan et al. (2011)

Nazarudeen (2010)

Padalia (2015)

Panda (2014)

Pandey (1998)

Pandey and Saini (2007)

Pandey and Pande (2016)

Pandey et al. (2015)

Pandey and Bora (1997)

Pant and Samant (2010)

Parinitha et al. (2004)

Parisara and Kiran (2016)

Patiri and Borah (2007)

Phoze et al. (2001)

Pradhan and Badola (2008)

Radha et al. (2013)

Rajasab and Isaq (2004)

Ramachandran (2007)

Ramachandran et al. (2009)

Rana et al. (2012)

Rasingam (2012)

Samydurai et al. (2012)

Sasi et al. (2011)

Sasi and Rajendran (2012)

Sarvalingam et al. (2015)

Sathyavathi and Janardhanan (2014)

Satyavani et al. (2015)

Singh A. et al. (2013)

Singh B. K. et al. (2013)

Singh et al. (2014)

Singh et al. (2011)

Sinha and Lakra (2007)

Srivastava (1998)

Sundriyal and Sundriyal (2001)

Sundriyal and Sundriyal (2003)

Suthari et al. (2014)

Swarnkar and Katewa (2008)

Thomas et al. (2011)

Tiwari et al. (2010)

Upreti et al. (2010)

Vikneshwaran et al. (2008)

Vishwakarma and Dubey (2011)

Yakang et al. (2013)

Yuhlung and Bhattacharyya (2014)

Yumnam et al. (2011)
Broad region

North

West

East

North

Central

North-east

North-east

North-east

North-east

South

South

North

East

North

Central

North

North-east

North-east

North

South

South

North-east

North-east

East

North

South

South

South

North

South

South

South

South

South

South

South

Central

North-east

North

North-east

East

North

East

East

South

West

Central

North

North

South

Central

North-east

North-east

North-east 
and semi-urban settings. In particular, the availability of plants collected from anthropogenic landscapes (i.e., the vicinity of rice fields, homesteads, forest patches, or fallow lands) and their easy access have often allowed a large fraction of people to depend on them as a valuable nutritional resource. In spite of an unprecedented diversity of WEP in India and their widespread consumption, comprehensive studies describing the general pattern are almost absent, e.g., what is the extent of the diversity of wild food spectra? What are the frequently used taxa? How does the pattern of consumption change with geography? Isolated studies have explored the taxonomic diversity, the part(s) used, and the method of processing before consumption, but stopped short of linking the findings with a larger countrywise pattern, which are crucial to perceive the magnitude of dependence on the wild resources and its implication for the usage of WEPs to be incorporated into food policy in order to make it more sustainable. In this study, we collected data to answer the following questions: (i) what is the taxonomic diversity of WEPs and their family-wise distribution? (ii) what is the pattern of use by parts? and (iii) how could an informeddecision be made to prioritize for policy on nutritional security?

\section{MATERIALS AND METHODS: (DETAILS IN SUPPLEMENTARY METHODS S1)}

\section{Study Plan, Data, and Source}

The studies suggest that the WEPs or their habitat are always under minimal to moderate direct or indirect manipulation (Turner et al., 2011). So, we adhered to this inclusive definition to consider WEP in our study and we have shortlisted 105 published articles describing the consumption of wild flora (Figure 1, Table 1). We carefully made the selection so that a fair representation of the food plant choice of the Indian subcontinent is reflected in our choice. We have tabulated the wild plant species, family, part(s) used, geographic location of the study, and the consuming communities. Species identity was confirmed through The Plant List (2010).

\section{Taxonomic Diversity, Distribution of Wild Edible Plants, and Use-Frequency}

We determined the diversity of food plants and evaluated species distribution across families. Further, in order to gain an insight into how the families contribute to the total species pool (number of species), we plotted total species (\%) against the number of families. In order to assess the popularity of a species, relative frequency of citation (RFC) was calculated.

\section{The Pattern of Use by Parts}

To gain an understanding of the use by parts, the total species pool is divided into six broad categories depending on the edible parts documented, i.e., seeds or grains, leaves and leafy shoots (including pteridophytes), flowers, fleshy fruits, underground parts (including true roots or various below-ground storage organs, such as, bulbs, corms, tubers, and rhizomes), and the others broadly following the classification by Turner et al. (2011). The creation of a sixth heterogenous group as "others" included plant parts other than first five, e.g., aril, bark, cambium,
TABLE 2 | Taxonomic diversity of the edible species, total and part-based.

\begin{tabular}{lcc}
\hline Plant parts & Family & Species \\
\hline Total & 184 & 1,403 \\
Seeds & 39 & 155 \\
Leaves or shoots & 134 & 740 \\
Flowers & 59 & 153 \\
Fruits & 110 & 657 \\
Underground parts & 70 & 219 \\
Others & 69 & 167 \\
\hline
\end{tabular}

peduncle, sap, bulbil, fruit body, petiole, pith, etc. Further, we also examined species distribution across families separately for each of the plant parts.

In order to uncover the importance of a species in terms of its edible parts, we have calculated the relative use value (RUV) of a selected set of species whose number of edible parts were equal to or $>3$. In addition, we have also determined consensus value for plant part (CPP) for selected high-ranking species derived from RUV and RFC values.

\section{Prioritization}

We sought to shortlist species building on information captured in two indices, RFC and RUV; it allowed us to formulate a scientifically-informed way of selecting a few from a large pool that could enable policy formulation.

\section{RESULTS}

\section{Taxonomic Diversity of Wild Edible Plants and Use-Frequency Spectra}

We found a total of 1,403 species belonging to 184 families (Table 2, Supplementary Table 1). In terms of species count, Leguminosae ranked first with 119 species with Compositae (57), Poaceae (53), Malvaceae (49), Rosaceae (48), Rubiaceae (42), Lamiaceae (41), Moraceae (39), Amaranthaceae (38), and Araceae (32) following it (Figure 2). When the species count was plotted against the number of families, it showed the top 17 families (9.2\% of the total families) contributed to nearly $50 \%$ (646 species) and the first 44 families $(23.9 \%$ of the families) captured about $75 \%$ (971 species) of the total species count (Figure 3).

RFC value segregated species based on their mentioned use in the number of studies and it varied from 0.012 to 0.46 (Table 3A). For instance, Oxalis corniculata, Amaranthus spinosus, Phyllanthus emblica, Colocasia esculenta, and Solanum americanum were the top five species with citation-frequencies of $0.46,0.393,0.371,0.348$, and 0.348 , respectively.

\section{The Pattern of Use by Parts}

On grouping total species according to the edible plant parts, the highest number of species seemed to be used as leafy greens (740 species from 134 families). Consumption as fruits ranked next to it (657 species from 110 families), followed by seeds, underground parts, and flowers (Table 2). When analyzed at a 
family level, Leguminosae was a highly speciose food plant family and topped the list in most of the categories, i.e., leaves-shoots (60 species), seeds (47 species), and flowers (27 species). In the other two categories, fruits and underground parts, Rosaceae (52 species) and Dioscoreaceae (23 species) had the highest number of edible species, respectively (Figures 4A-E).

The range of relative use-value (RUV) varied from 0.5 to 1 , however, only one species, Nymphaea nouchali demonstrated a RUV of one, followed by Nymphaea rubra and Cannabis sativa each with RUV 0.83. There were 10 species (e.g., Nelumbo nucifera, Tamarindus indica, Spondias pinnata, Typha domingensis, etc.) with a moderately high RUV of 0.67 (Table 3B). Around 33 species (e.g., Boehmeria glomerulifera, Ficus hispida, Urtica parviflora, several Allium species) demonstrated a RUV of 0.5 (data not shown).

Ranking based on CPP value uncovered a list of edible plant parts which are widely consumed, and its value ranged from zero to one (Tables 4 A,B). Since the index quantified the acceptability of a plant part among consumers and scored it accordingly, it thereby segregated species in terms of their most valued plant part(s). A few examples of this are: seeds of Cajanus scarabaeoides (0.44), Cannabis sativa (0.33), Euryale ferox (0.357),
Nelumbo nucifera (0.218); leaves and shoots of Amaranthus spinosus (0.97), Centella asiatica (0.85), Oxalis corniculata (0.8), Ipomoea aquatica (0.95); flowers of Bauhinia variegata (0.625), Typha domingensis (0.362), Moringa concanensis (0.285); fruits of Ficus racemosa (0.91), Ziziphus jujuba (0.846), Spondias pinnata (0.727), and underground parts of Dioscorea bulbifera (0.896), Dioscorea pentaphylla (0.889), Asparagus racemosus (0.77), etc.

\section{Prioritization}

We shortlisted a set of species for prioritization based on RFC and RUV values (Table 5) in the following manner: (i) highest priority species: it included species which populated both lists, one with a top 25 species scoring $50 \%$ of the RFC value (0.213) and the other with an RUV (0.5). fFour species, s Tamarindus indica, Phyllanthus emblica, Colocasia esculenta, and Spondias pinnata, were on the list; (ii) high priority: The rest of the 20 species were in the top 24 species that scored $50 \%$ of the RFC value $(0.213)$ or above, e.g., Oxalis corniculata, Amaranthus spinosus, Centella asiatica, Ziziphus jujuba, Solanum americanum, Amaranthus viridis, Commelina benghalensis, Dioscorea pentaphylla, etc; (iii) medium to high priority: a set of nine species with four or more edible parts

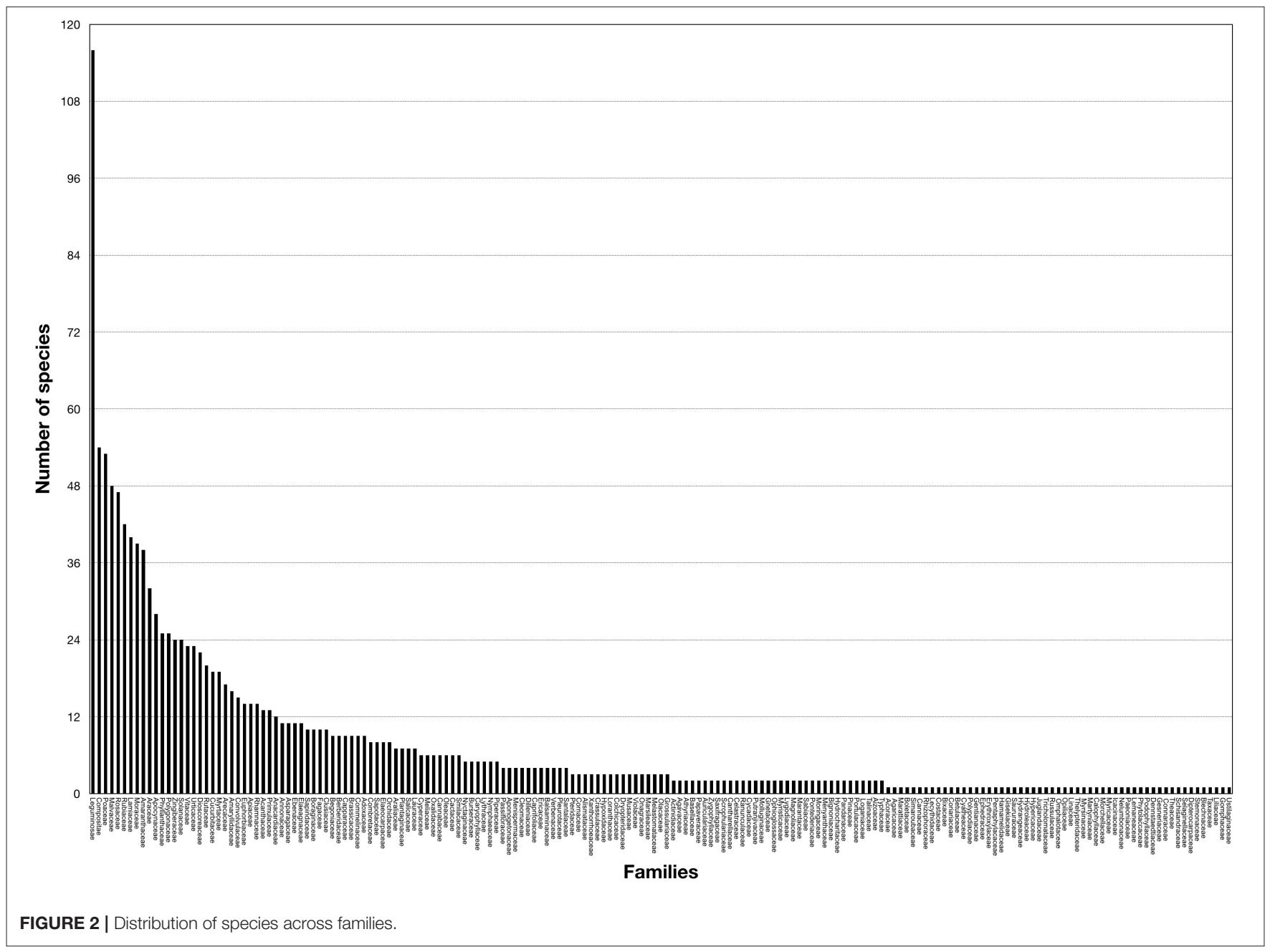




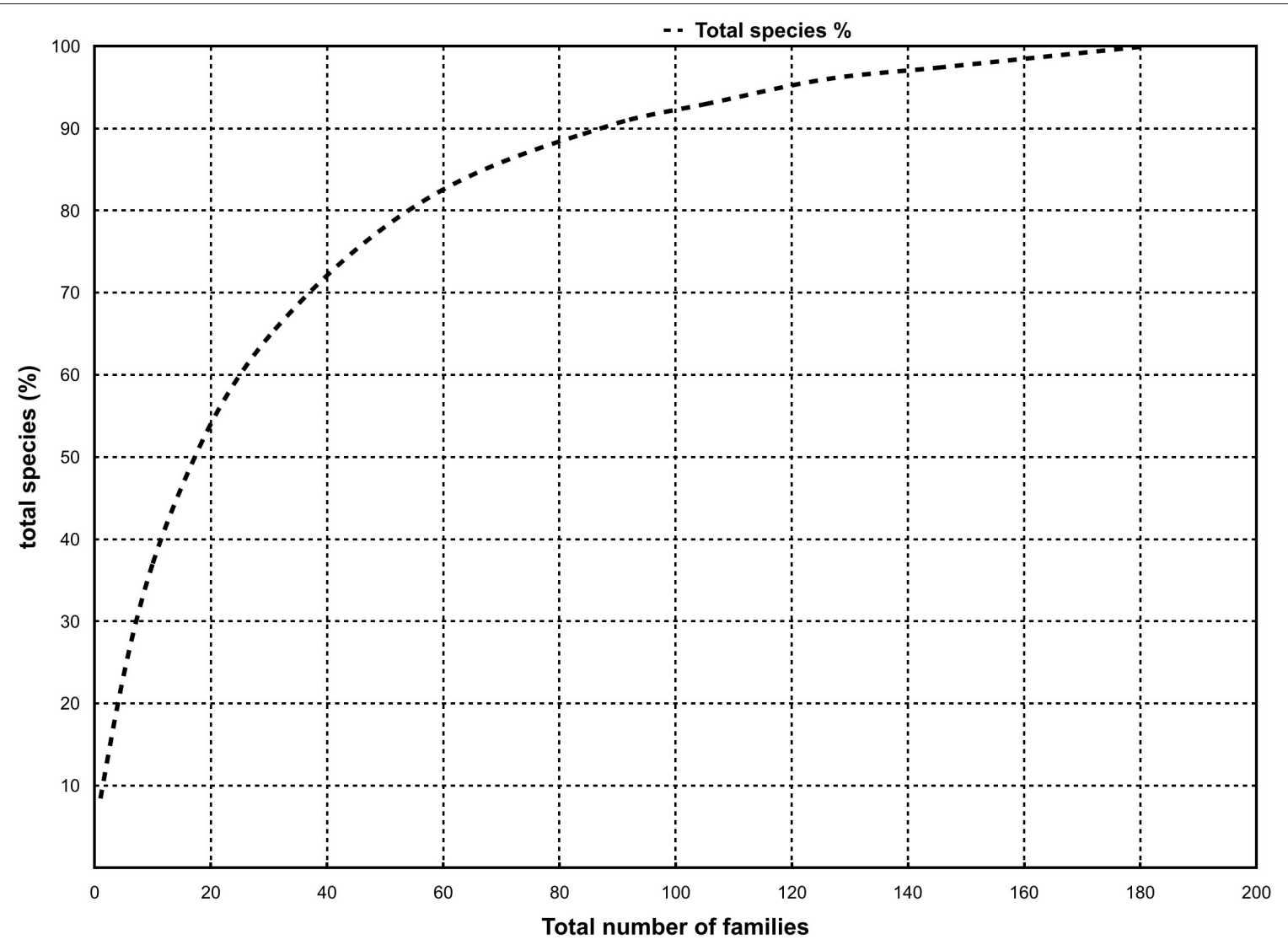

FIGURE 3 | Contribution of families to the total species pool (\%).

based on an RUV value between 1 and 0.67 were enlisted, such as Nelumbo nucifera, Nymphaea rubra, N. nouchali, Justicia adhatoda, Cannabis sativa, etc. Relying on the above information, we selected a set of 32 species based on RFC and RUV values for prioritization. This collection of species has been widely used as food sources throughout the country, even in disjunct geographic regions, implying greater acceptance among communities.

\section{DISCUSSION}

A culture of WEP collection from nearby forested patches, fringes of agricultural fields, or from the homestead has been ubiquitous in developing and many developed countries. It constituted a healthy and sustainable food system widely documented across the globe (Scoones et al., 1992; Mazhar et al., 2007; Bharucha and Pretty, 2010; Rowland et al., 2016). Determining the popularity of such an exercise within India revealed a remarkable diversity of wild flora in regular use. Of which, many of these have been used across widely divergent cultural geographic regions or have multiple useful edible organs. In addition, being a standard component of daily diet, the contribution of wild food to food uncertainty, shortages, and agricultural regression has widely been acknowledged (Ertug, 2014). It suggests the habit of eating wild plants falls in the larger domain of human environment interactions and has evolved over many generations to help manage natural resources.

\section{Taxonomic Diversity}

A series of regional studies have uncovered the great wealth of wild flora being used as food that has not entered into mainstream cultivation (Singh and Arora, 1978; Sinha and Lakra, 2005; Angami et al., 2006; Jeyaprakash et al., 2011). Similarly, the diverse spectra of edible plant species (1403 species) belonging to nearly 200 families reflect that it has been a deep-rooted practice in India. Inclusion of a wide variety of plants of different habits, growth forms, and usable organs in the dietary repertoire also underscores their acceptance and assimilation into food culture. The breadth of plant use is high compared to the other countries or regions (such as Southeast Asia or the Mediterranean), which seems plausible given the enormous size of the country and its inherent bio-cultural diversity (Loh and Harmon, 2005; Maffi and Woodley, 2012). The choice of food or medicinal species is often governed by many factors, where plant availability is a primary driver. Plant availability and distribution are largely determined by environmental parameters, e.g., soil type, temperature, altitude, rainfall, etc., that significantly affect the peoples' choices (Turner et al., 2011; Chevalier et al., 2014b). India covers a large geographic expanse with a high 


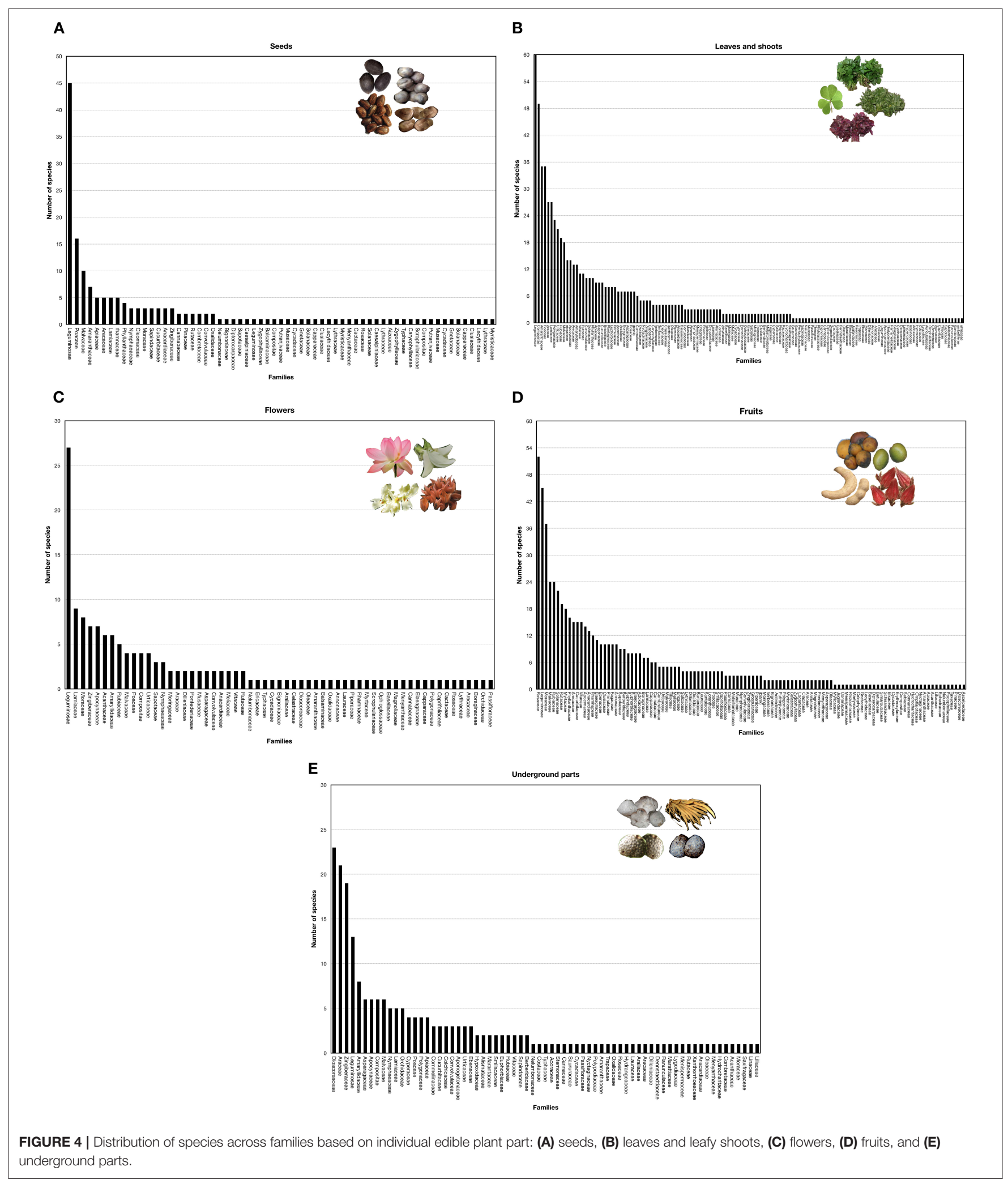

floral diversity, which harbors many biogeographic zones and hotspots that shelter a wide diversity of plants (Nayar, 1996). In addition, the high bio-cultural diversity has resulted in the divergent human adaptation to manage and use an enormous variety of plant resources in a dynamic manner (Berkes, 2009; Maffi and Woodley, 2012; Chevalier et al., 2014b). This fact is 
TABLE 3A | A list of species with high RFC value (up to $50 \%$ of the maximum).

\begin{tabular}{lll}
\hline Species & Number of studies mentioning use & RFC \\
\hline Oxalis corniculata & 41 & 0.39 \\
Amaranthus spinosus & 35 & 0.33 \\
Phyllanthus emblica & 33 & 0.31 \\
Colocasia esculenta & 31 & 0.295 \\
Solanum americanum & 31 & 0.295 \\
Centella asiatica & 31 & 0.295 \\
Amaranthus viridis & 29 & 0.28 \\
Chenopodium album & 28 & 0.27 \\
Dioscorea bulbifera & 27 & 0.26 \\
Commelina benghalensis & 26 & 0.25 \\
Alternanthera sessilis & 26 & 0.25 \\
Dioscorea pentaphylla & 26 & 0.25 \\
Ziziphus jujuba & 24 & 0.23 \\
Portulaca oleracea & 23 & 0.22 \\
Senna tora & 22 & 0.22 \\
Boerhavia diffusa & 22 & 0.22 \\
Ipomoea aquatica & 22 & 0.22 \\
Ficus racemosa & 21 & 0.2 \\
Tamarindus indica & 21 & 0.2 \\
Asparagus racemosus & 21 & 0.2 \\
Aegle marmelos & 21 & 0.2 \\
Diplazium esculentum & 21 & 0.2 \\
Solanum torvum & 20 & 0.19 \\
Moringa oleifera & 19 & 0.181 \\
Spondias pinnata & & 0.181 \\
\hline & & \\
& 21 & \\
\hline
\end{tabular}

TABLE 3B | A list of species with multiple edible parts and RUV value (between 0.67 and 1)

\begin{tabular}{lcc}
\hline Species & $\begin{array}{c}\text { Number of edible } \\
\text { parts }\end{array}$ & RUV \\
\hline Nymphaea nouchali Burm.f. & 6 & 1 \\
Nymphaea rubra Roxb. ex & 5 & 0.83 \\
Andrews & & \\
Cannabis sativa L. & 5 & 0.83 \\
Nelumbo nucifera Gaertn. & 4 & 0.67 \\
Tamarindus indica L. & 4 & 0.67 \\
Justicia adhatoda L. & 4 & 0.67 \\
Spondias pinnata (L. f.) Kurz & 4 & 0.67 \\
Ensete superbum (Roxb.) & 4 & 0.67 \\
Cheesman & & \\
Typha domingensis Pers. & 4 & 0.67 \\
Bauhinia variegata L. & 4 & 0.67 \\
Aesculus indica (Wall. ex & 4 & 0.67 \\
Cambess.) Hook. & & \\
Phyllanthus emblica L. & 4 & 0.67 \\
\hline
\end{tabular}

also reflected in the array of WEP species regularly consumed by people.

Although a rich collection of WEP is in the spectrum of food choice, we uncovered a preponderance of a handful of families (forty-four families make up about $75 \%$ of the total species count). Human preference for a narrow subset from a large pool of floral families is a common trend that has been previously observed in medicinal plant use, and researchers strove to explain the underlying reason (Moerman, 1996; Leonti et al., 2003). The same trend of over- and under-use has also been noted in wild edibles, though not explicitly stated (Turner et al., 2011). The predominance of Leguminosae (8\%) has been reported from elsewhere in Southeast Asia; likewise, the top ten speciose families shown in our results, such as Poaceae, Rosaceae, Moraceae, Lamiaceae, Compositae, Araceae, etc., have also been reported from studies carried out in Southeast Asia (Cruz-Garcia and Price, 2011; Sujarwo et al., 2014; Shin et al., 2018). On the other hand, the peoples' choices in European countries remained with Rosaceae, Liliaceae, Lamiaceae, Asteraceae, and Apiaceae members, whereas there was a visible absence of Poaceae, Moraceae, Amaranthaceae, Malvaceae, and a minimal presence of Leguminosae (Leonti et al., 2006; Tardío et al., 2006; Pardo-deSantayana et al., 2007; Hadjichambis et al., 2008; González et al., 2011; Dogan et al., 2013). The underlying reason of the sharing of edible flora could be due to a strong biogeographic affinity between South and Southeast Asia, where the Indo-Malayan biota represented a major fraction (Mani, 1974). A study carried out in South Africa by Ogle and Grivetti (1985a) revealed a prevalence of selected families, such as Compositae, Myrtaceae, Moraceae, Rubiaceae, Leguminosae, and Amaranthaceae that broadly overlap with Asian assemblage.

Likewise, a strong bias in choosing certain species has also been observed. It seems that some species were more overly used than others, a fact which was reflected in their RFC value spectrum. The index also signified an apparent importance of the species in terms of its frequency of use (i.e., how many times it has been cited considering all the studies?) and the degree of its acceptance among various communities (i.e., what is the spatial limit of its use?). For example, Alternanthera sessilis, a highrank species with a magnitude of RFC 0.29 , is a plant which has been widely used from southern to north-eastern through eastern India. Likewise, there were many members which demonstrated a similarly wider acceptance, e.g., Oxalis corniculata, Amaranthus spinosus, Centella asiatica, etc. Throughout literature, the choice of certain taxa has widely been reported from studies on Asia, Europe, and Africa; only the preferred set of species varied with geography (Ogle and Grivetti, 1985a,b; Tardío et al., 2006; Hadjichambis et al., 2008; Cruz-Garcia and Price, 2011; Sujarwo et al., 2014). The underlying drivers of peoples' choices could be multiple, e.g., abundance, easy accessibility, taste, prior knowledge or experience, etc. (Chevalier et al., 2014b; Albuquerque et al., 2015). On the other hand, there were also instances where commonly available species had a narrow use in culinary practices, perhaps due to lack of information, or cultural inclination. Examples can be drawn from Tephrosia purpurea, Albizia odoratissima, Leucas stricta, and Gmelina arborea which are locally relished (RFC 0.011 for each).

\section{Use by Parts}

Plant/people interactions have been the backbone of human evolution, since all cultures have to subsist on plant resources (Cruz-Garcia and Ertug, 2014). Humans have employed a diverse 
collection of floral parts in their diets for a long time, e.g., fleshy leafy shoots, underground starch-rich parts, ripe and unripe fruits, flowers, and seeds. Additionally, many other parts are also regularly consumed, such as pith, bark, arils, peduncles, bulbils, latex, etc. Of these, prehistory is replete with examples of the harvest of various roots and tubers to derive starchy food (Ezell et al., 2006). Other examples, such as the charred remains of seeds or grains, were also often uncovered in archeological specimens (Harris and Hillman, 2014; Melamed et al., 2016); absent were the leaves or tender shoots or flowers. Altogether, the range highlights divergent human choice and their post-harvest processing that had established its roots from the huntinggathering phase (Chevalier et al., 2014a,b).

In our study, the grouping of WEP based on edible parts has offered a deeper understanding of the underlying trend of use, i.e., how edible parts drive plant use, which parts are being eaten the most, etc. From total used species, it was revealed that most have been used as leafy greens (52.7\%) and fruits (47.6\%), followed by underground parts (15.7\%), seeds $(12.8 \%)$, and flowers (11.2\%). Turner et al. (2011) underscored the preference toward the specific type of wild edible consumption and attributed it to prevailing climatic condition in an ecosystem that perhaps determines peoples' choice. They also highlighted the role of culture in shaping the type of wild edible use, such as the frequent use of leafy greens in east and south Asia being in vogue. In a study conducted by Cruz-Garcia and Price (2011), the highest edible species clustered in the "shoot" and "fruit" category; however, their grouping does not entirely match with the part-wise classification we implemented. Similar leaning on wild leafy green use has also been reported by Sujarwo et al. (2014) in Bali. The inclination toward leafy greens is a common observation across the east Asian countries, such as Korea (Pemberton and Lee, 1996), Thailand (Price, 2006), Vietnam (Ogle, 2001), and China (Hu, 2005) and is often termed as herbophilia (Luczaj, 2008) to refer to peoples' liking of leafy greens. It is in sharp contrast with northern Europe where wild vegetables have been used very little (Luczaj, 2008), or in the Amazon where they are hardly used at all (Katz et al., 2012).

When the edible species pool is broken into six categories of the basis of parts, Leguminosae outnumbered other families in most of the categories, i.e., seeds, flowers, and shoots. It is also the second largest family in the fruit category and the fourth largest in underground parts. One underlying reason could be the unprecedented species diversity of Leguminosae in the tropics. The predominance of Leguminosae members has also been a common finding in several similar studies from the southeast Asian countries where it contributes significantly to the floral diversity (Cruz-Garcia and Price, 2011). Likewise in the fruit category, an abundance of Rosaceous species could be a reflection of the overall high use

TABLE 4A | CPP value for selected plants with highest RFC value.

\begin{tabular}{|c|c|c|c|c|c|c|}
\hline Species & Total number of citations of all parts & CPP(se) & CPP(I-sh) & CPP(fl) & $\mathrm{CPP}(\mathrm{fr})$ & $\mathrm{CPP}(\mathrm{u})$ \\
\hline Oxalis corniculata & 41 & 0.024 & 0.804 & 0.024 & 0.121 & 0 \\
\hline Amaranthus spinosus & 35 & 0 & 0.971 & 0 & 0 & 0 \\
\hline Phyllanthus emblica & 33 & 0.03 & 0.061 & 0.879 & 0 & 0 \\
\hline Colocasia esculenta & 53 & 0 & 0.377 & 0.113 & 0 & 0.433 \\
\hline Solanum americanum & 39 & 0 & 0.487 & 0 & 0.513 & 0 \\
\hline Chenopodium album & 30 & 0.067 & 0.933 & 0 & 0 & 0 \\
\hline Dioscorea bulbifera & 29 & 0 & 0.034 & 0 & 0.034 & 0.896 \\
\hline Commelina benghalensis & 27 & 0 & 0.852 & 0 & 0 & 0.111 \\
\hline Alternanthera sessilis & 26 & 0 & 1 & 0 & 0 & 0 \\
\hline Dioscorea pentaphylla & 27 & 0 & 0 & 0.074 & 0 & 0.889 \\
\hline Boerhavia diffusa & 24 & 0 & 0.792 & 0 & 0.042 & 0.083 \\
\hline Ipomoea aquatica & 23 & 0 & 0.957 & 0 & 0.043 & 0 \\
\hline Ficus racemosa & 23 & 0 & 0 & 0 & 0.913 & 0.043 \\
\hline Tamarindus indica & 33 & 0.152 & 0.242 & 0.091 & 0.515 & 0 \\
\hline Asparagus racemosus & 22 & 0 & 0.091 & 0.091 & 0.045 & 0.773 \\
\hline Aegle marmelos & 22 & 0 & 0.091 & 0 & 0.091 & 0 \\
\hline Diplazium esculentum & 20 & 0 & 1 & 0 & 0 & 0 \\
\hline Solanum torvum & 20 & 0 & 0.05 & 0 & 0.95 & 0 \\
\hline Moringa oleifera & 30 & 0.033 & 0.4 & 0.233 & 0.333 & 0 \\
\hline Spondias pinnata & 22 & 0.045 & 0.091 & 0.091 & 0.727 & 0 \\
\hline
\end{tabular}


TABLE 4B | CPP value for selected plants with RUV value between 0.5 and 1.

\begin{tabular}{|c|c|c|c|c|c|c|}
\hline Colocasia esculenta & 53 & 0 & 0.377 & 0.113 & 0 & 0.434 \\
\hline Phyllanthus emblica & 33 & 0.030 & 0.061 & 0 & 0.879 & 0 \\
\hline Tamarindus indica & 33 & 0.152 & 0.242 & 0.091 & 0.515 & 0 \\
\hline Nelumbo nucifera & 32 & 0.218 & 0.156 & 0.187 & 0 & 0.406 \\
\hline Moringa oleifera & 30 & 0.033 & 0.4 & 0.233 & 0.333 & 0 \\
\hline Bauhinia variegata & 16 & 0 & 0.25 & 0.625 & 0 & 0.0625 \\
\hline Euryale ferox & 14 & 0.357 & 0.357 & 0 & 0.142 & 0.071 \\
\hline Ensete superbum & 13 & 0.077 & 0.308 & 0.231 & 0.307 & 0 \\
\hline Ficus hispida & 13 & 0 & 0.153 & 0.077 & 1 & 0 \\
\hline Dendrocalamus strictus & 12 & 0.167 & 0.583 & 0.083 & 0 & 0.167 \\
\hline Justicia adhatoda & 10 & 0 & 0.5 & 0.3 & 0.1 & 0.1 \\
\hline Cannabis sativa & 9 & 0.333 & 0.333 & 0.111 & 0.111 & 0 \\
\hline Cajanus scarabaeoides & 9 & 0.444 & 0.222 & 0 & 0.222 & 0.111 \\
\hline Alpinia galanga & 9 & 0.11 & 0 & 0.22 & 0 & 0.67 \\
\hline Nymphaea rubra & 8 & 0.25 & 0.125 & 0 & 0.25 & 0.25 \\
\hline Borassus flabellifer & 8 & 0.125 & 0.125 & 0.125 & 0.625 & 0 \\
\hline Moringa concanensis & 7 & 0 & 0.428 & 0.285 & 0.285 & 0 \\
\hline Holostemma ada-kodien & 6 & 0 & 0.333 & 0.167 & 0.167 & 0.333 \\
\hline Dregea volubilis & 6 & 0 & 0.333 & 0.167 & 0.5 & 0 \\
\hline Fagopyrum acutatum & 6 & 0.167 & 0.667 & 0 & 0 & 0.167 \\
\hline Allium humile & 5 & 0 & 0.6 & 0.2 & 0 & 0.2 \\
\hline Murraya paniculata & 4 & 0 & 0.25 & 0.25 & 0.5 & 0 \\
\hline Boehmeria glomerulifera & 3 & 0 & 0.333 & 0.333 & 0.333 & 0 \\
\hline Urtica parviflora & 3 & 0 & 0.333 & 0.333 & 0 & 0.333 \\
\hline Allium carolinianum & 3 & 0 & 0.333 & 0.333 & 0 & 0.333 \\
\hline Allium jacquemontii & 3 & 0 & 0.333 & 0.333 & 0 & 0.333 \\
\hline Allium tuberosum & 3 & 0 & 0.333 & 0.333 & 0 & 0.333 \\
\hline Trichosanthes tricuspidata & 3 & 0.333 & 0.333 & 0 & 0 & 0.333 \\
\hline Fagopyrum acutatum & 3 & 0.333 & 0.333 & 0 & 0 & 0.333 \\
\hline
\end{tabular}

[CPP(se) - CPP value for seeds, CPP(l-sh) - CPP value for leafy shoots, CPP(fl) - CPP value for flower, CPP(fr) - CPP value for fruits, CPP(u) - CPP value for underground parts].

breadth of Rosaceae members, as reported from Mediterranean or European countries (Tardío et al., 2006; Luczaj, 2012). Rosaceae is an important family which generally shares major floral elements that have been formally cultivated for fruits. In the root and tuber category, members of Dioscoreaceae, Araceae, Zingiberaecae, and Amaryllidaceae outnumbered others, which is also in concord with other studies (Turner et al., 2011).
Evaluation of species' importance in terms of their multiple palatable plant parts made use of the index, RUV, that selected and ranked edible species based on the number of useful parts. Likewise, an inclusion of CPP value added a reliability measure to the various edible parts of species selected for prioritization. Collectively, the indices (RFC and RUV) allowed an informed decision on shortlisting species based on the analyses of the collected data. 
TABLE 5 | A list prioritized species based on RFC and RUV values.

\begin{tabular}{|c|c|c|}
\hline $\begin{array}{l}\text { Highest priority } \\
\text { species }\end{array}$ & High priority species & $\begin{array}{l}\text { Medium to high } \\
\text { priority species }\end{array}$ \\
\hline $\begin{array}{l}\text { Colocasia } \\
\text { esculenta (L.) } \\
\text { Schott }\end{array}$ & Aegle marmelos (L.) Corrêa & $\begin{array}{l}\text { Aesculus indica (Wall. } \\
\text { ex Cambess.) Hook. }\end{array}$ \\
\hline $\begin{array}{l}\text { Phyllanthus } \\
\text { emblica L. }\end{array}$ & $\begin{array}{l}\text { Alternanthera sessilis (L.) } \\
\text { R.Br. ex DC. }\end{array}$ & Bauhinia variegata $\mathrm{L}$. \\
\hline $\begin{array}{l}\text { Spondias pinnata } \\
\text { (L. f.) Kurz }\end{array}$ & Amaranthus spinosus L. & Cannabis sativa $\mathrm{L}$. \\
\hline \multirow[t]{17}{*}{$\begin{array}{l}\text { Tamarindus indica } \\
\text { L. }\end{array}$} & Amaranthus viridis $\mathrm{L}$. & $\begin{array}{l}\text { Ensete superbum } \\
\text { (Roxb.) Cheesman }\end{array}$ \\
\hline & $\begin{array}{l}\text { Asparagus racemosus } \\
\text { Willd. }\end{array}$ & Justicia adhatoda L. \\
\hline & Boerhavia diffusa L. & $\begin{array}{l}\text { Nelumbo nucifera } \\
\text { Gaertn. }\end{array}$ \\
\hline & Centella asiatica (L.) Urb. & $\begin{array}{l}\text { Nymphaea nouchali } \\
\text { Burm.f. }\end{array}$ \\
\hline & Chenopodium album L. & $\begin{array}{l}\text { Nymphaea rubra Roxb. } \\
\text { ex Andrews }\end{array}$ \\
\hline & Commelina benghalensis L. & $\begin{array}{l}\text { Typha domingensis } \\
\text { Pers. }\end{array}$ \\
\hline & Dioscorea bulbifera L. & \\
\hline & Dioscorea pentaphylla L. & \\
\hline & $\begin{array}{l}\text { Diplazium esculentum } \\
\text { (Retz.) Sw. }\end{array}$ & \\
\hline & Ficus racemosa L. & \\
\hline & Ipomoea aquatica Forssk. & \\
\hline & Oxalis corniculata L. & \\
\hline & Portulaca oleracea L. & \\
\hline & Senna tora (L.) Roxb. & \\
\hline & Solanum americanum Mill. & \\
\hline & Solanum torvum Sw. & \\
\hline & Ziziphus jujuba Mill. & \\
\hline
\end{tabular}

\section{Prioritization-Inclusion in Policy for Nutritional Security}

Assimilation of wild edible plants into the diet has much larger implications in terms of environmental sustainability, when the world is plagued with the grave crises of climate change and food insecurity, and could lessen the footprints of agriculture and allow for a shift toward more sustainable food systems. Judicious use of intrinsic resources with less negative impact has become critical and adoption of WEP resources could emerge as a sustainable strategy (Bharucha and Pretty, 2010). Wild food offers several advantages on this line, i.e., wide diversity, easy access to the local resource base, availability, time-tested reliability, little or no management, etc. (Mazhar et al., 2007; Bharucha and Pretty, 2010; Cruz-Garcia and Price, 2011; Turner et al., 2011). Moreover, the problem of micronutrient deficiency or "hidden hunger" that looms large over the global population cannot be erased by staple crops which lack essential micronutrients (Guralnik et al., 2004; Pingali, 2015; Ickowitz et al., 2019). Yet fortification of commercial food and production of bio-fortified food crops bred with increased micronutrient content have also been proposed to combat hidden hunger. Here, the untapped nutritional potential of wild food to enhance dietary diversity and nutritional outcome has a central role to play (Table 6). They are reservoirs of many vitamins andtrace elements, e.g., leafy shoots (e.g., Boerhaavia diffusa, Aerva lanata) are a source of vitamin $\mathrm{A}$ and Calcium, fruits (Tamarindus indica), are a source of iron and zinc, etc. Their health benefits have also been widely reported from various countries with a tradition of eating wild edibles (Ogle and Grivetti, 1985a,b; Cook et al., 2000; Ogle, 2001; Ogle et al., 2003; Simopoulos, 2004; Uusiku et al., 2010; Ranfa et al., 2014; Mishra et al., 2015; Hama-Ba et al., 2017). A couple of studies examining selected edible plants from various parts of India (such as Sikkim, Jharkhand, the north-eastern region, and South India) also supports the same fact (Rajyalakshmi et al., 2001; Sundriyal and Sundriyal, 2001; Bhatt et al., 2005; GhoshJerath et al., 2015). In sum, positive health implications of wild edibles have long been acknowledged either formally through research or informally through age-long traditional wisdom. Nevertheless, owing to several entangled factors, the practice is currently at stake.

One of the largely agreed reasons is agricultural intensification that has substantially increased the staple crop production, but has significantly reduced farmland biodiversity and dietary diversity (Dewey, 1981; Fowler and Mooney, 1990; Pretty, 1995; Pingali, 2015). It has also brought in an intensive use of agrochemicals that acted in tandem with other factors like landuse change, forest fragmentation, and a change in governance to decimate the wild population of edible plants or their habitat (Pretty, 1995; Bharucha and Pretty, 2010; Padoch and Sunderland, 2014; Broegaard et al., 2017; Ickowitz et al., 2019). Many other cultural factors, e.g., changing food habit, loss of traditional knowledge systems, the overwhelming presence of dominant food culture, and easy access to store food have also acted hand in hand to erode the culture of eating wild food (Luczaj, 2012). The eventual outcome is a loss of dietary diversity and disruption of the sustainable food systems. Here, the lower strata of economic groups of developing countries are worst hit as the malnourishment owing to micronutrient deficiency is acute among rural populations (Von Grebmer et al., 2014). It is because the decline of wild edibles population robbed them of the easily obtainable nutrition and buying the equivalent food items from the market place always incurred an extra cost, thus impairing the access. It is especially imperative for a developing country like India, where a major section of the population cannot afford to buy essential nutrients from nearby markets for various reasons, price being the primary reason, and where the nutritional benefits of local resources in the form of wild edibles in social welfare cannot be undermined.

A potential way out could be the revival of the culture by promoting informal cultivation or moderate management in homesteads, fringes, pastures, or fallow lands (Broegaard et al., 2017). The issue deserves a synergy among research, education and outreach, and policy. For the resumption of such an exercise, a prioritization program would be a better point to commence if bolstered by data-driven inference; here we aim to objectively prioritize a handful of plants that might facilitate 


\begin{tabular}{|c|c|c|c|c|c|c|c|c|c|c|c|c|c|c|c|c|c|}
\hline Edible species & Parts & Vit A & Vit B1 & Vit B2 & Vit C & Vit E & $\mathrm{Ca}$ & $\mathrm{Fe}$ & $\mathrm{Zn}$ & $\mathrm{Na}$ & $\mathbf{K}$ & $\mathrm{Cu}$ & $\mathbf{P}$ & Mg & Mn & $\mathrm{Se}$ & Folic acid \\
\hline Aegle marmelos & $\mathrm{Fr}$ & 186 & 0.01 & 1.2 & $x$ & $x$ & 85 & 0.6 & $x$ & $x$ & 0.6 & $x$ & 31.8 & $x$ & $x$ & $x$ & $x$ \\
\hline Aerva lanata & L, Sh & 21.76 & $x$ & $x$ & 19 & $x$ & 322 & 22.06 & 0.65 & 10.4 & $x$ & $x$ & $x$ & $x$ & $x$ & $x$ & 0.04 \\
\hline Aesculus indica & Se & $x$ & $x$ & $x$ & $x$ & $x$ & 8.20 & 8.50 & 705.9 & $x$ & 81.00 & 0.6 & $x$ & $x$ & 0.5 & $x$ & $x$ \\
\hline Agaricus sp. (Chiple) & $\begin{array}{l}\text { Fruit } \\
\text { body }\end{array}$ & $\mathrm{x}$ & $x$ & $x$ & $x$ & $x$ & 1.842 & 0.13 & 0.73 & 0.053 & 1.92 & 0.07 & 0.47 & 0.23 & $x$ & $x$ & $\mathrm{x}$ \\
\hline $\begin{array}{l}\text { Agaricus sp. } \\
\text { (Patpate) }\end{array}$ & $\begin{array}{l}\text { Fruit } \\
\text { body }\end{array}$ & $x$ & $x$ & $x$ & $x$ & $x$ & 1.53 & 0.11 & 0.6 & 0.06 & 2.17 & 0.09 & 0.76 & 0.34 & $x$ & $x$ & $x$ \\
\hline Alternanthera sessilis & L, Sh & 1.92 & 0 & 0.14 & 17 & $x$ & 510 & 1.63 & $x$ & $x$ & $x$ & $x$ & $\mathrm{x}$ & $x$ & $x$ & $x$ & $x$ \\
\hline Amaranthus spinosus & L, Sh & 3.56 & 0 & $x$ & 33 & $x$ & 800 & 22.9 & $x$ & $x$ & $x$ & $x$ & $x$ & $x$ & $x$ & $x$ & $x$ \\
\hline Amaranthus tricolor & L, Sh & 5.52 & 0.03 & 0.3 & 99 & $x$ & 397 & 3.49 & 0.18 & 230 & $x$ & $x$ & $x$ & $x$ & $x$ & $x$ & 0.14 \\
\hline Amaranthus viridis & L, Sh & $x$ & $x$ & $x$ & 179 & $x$ & 330 & 18.7 & $x$ & $x$ & $x$ & $x$ & $x$ & $x$ & $x$ & $x$ & $x$ \\
\hline Antidesma acidum & L, Sh & $x$ & $x$ & $x$ & $x$ & $x$ & 1717 & $x$ & $x$ & $x$ & $x$ & $x$ & $x$ & $x$ & $x$ & $\mathrm{x}$ & $x$ \\
\hline Aralia leschenaultii & $\mathrm{Fr}$ & $\mathrm{x}$ & $x$ & $x$ & $x$ & $x$ & 0.31 & 0.6 & $x$ & 0.6 & 1.89 & $x$ & 0.47 & 0.25 & $x$ & $x$ & $\mathrm{x}$ \\
\hline Ardisia macrocarpa & $\mathrm{Fr}$ & $x$ & $x$ & $x$ & $x$ & $x$ & 0.29 & 0.02 & 0.31 & 0.04 & 0.89 & 0.07 & 0.13 & 0.31 & $x$ & $x$ & $x$ \\
\hline Arisaema utile & $\mathrm{Fr}$ & $x$ & $x$ & $x$ & $x$ & $x$ & 0.92 & 0.83 & $x$ & 0.09 & 2.4 & $x$ & 0.69 & 0.62 & $x$ & $x$ & $x$ \\
\hline Artocarpus lakoocha & $\mathrm{Fr}$ & 0.25 & 0.02 & 0.15 & 135 & $x$ & 50 & 0.05 & $x$ & $x$ & $x$ & $x$ & $x$ & $x$ & $x$ & $x$ & $x$ \\
\hline Baccaurea ramiflora & $\mathrm{Fr}$ & $x$ & $x$ & $x$ & 0.27 & $x$ & 0.16 & 0.08 & 0.6 & 0.04 & 0.73 & 0.08 & 0.13 & 0.5 & $x$ & $x$ & $x$ \\
\hline Bambusa bambos & L, Sh & 0 & 0.08 & 0.19 & 5 & $x$ & 20 & 0.1 & $x$ & $x$ & $x$ & $x$ & $x$ & $x$ & $x$ & $x$ & $x$ \\
\hline Bambusa tulda & L, Sh & $\mathrm{x}$ & $\mathrm{x}$ & $x$ & 1.42 & 0.61 & 4.06 & 3.19 & 0.72 & 19.96 & 408 & 0.44 & $x$ & $x$ & $x$ & $\mathrm{x}$ & $x$ \\
\hline Bauhinia purpurea & L, Sh & $\mathrm{x}$ & $\mathrm{x}$ & $\mathrm{x}$ & $\mathrm{x}$ & $x$ & 312 & $\mathrm{x}$ & $x$ & $x$ & $x$ & $x$ & $x$ & $x$ & $x$ & $x$ & $\mathrm{x}$ \\
\hline Boerhaavia diffusa & L, Sh & 16.01 & $x$ & $\mathrm{x}$ & 12 & $x$ & 202 & 10.68 & 0.41 & 39.4 & $x$ & $x$ & $\mathrm{x}$ & $x$ & $x$ & $\mathrm{x}$ & 0.02 \\
\hline Cannabis sativa & L, Sh & $x$ & 0.4 & 0.1 & $x$ & 90 & 145 & 14 & 7 & 12 & 859 & 2 & $x$ & 483 & 7 & $x$ & $x$ \\
\hline Carissa carandas & $\mathrm{Fr}$ & $x$ & $x$ & $x$ & $x$ & $x$ & 21 & $x$ & $x$ & $x$ & $x$ & $x$ & $x$ & $x$ & $x$ & $x$ & $x$ \\
\hline Castanopsis indica & $\mathrm{Fr}$ & $x$ & $x$ & $x$ & $x$ & $x$ & 1540 & 2.6 & 1.53 & 0.03 & 4.33 & 0.77 & 80 & 12.68 & 2.35 & 0.0006 & $x$ \\
\hline Celosia argentea & L, Sh & $x$ & $x$ & $x$ & $x$ & $x$ & 323 & $x$ & $x$ & $x$ & $x$ & $x$ & $x$ & $x$ & $x$ & $x$ & $x$ \\
\hline Centella asiatica & L, Sh & 0.5 & 0.53 & $x$ & 5 & $x$ & 231 & 55.66 & 1.92 & 5.2 & $x$ & $x$ & $x$ & $x$ & $x$ & $\mathrm{x}$ & 0.01 \\
\hline Chenopodium album & L, Sh & 1.74 & 0.01 & 0.14 & 35 & $x$ & 150 & 4.2 & $x$ & $x$ & $x$ & $x$ & $x$ & $x$ & $x$ & $x$ & $x$ \\
\hline $\begin{array}{l}\text { Choerospondias } \\
\text { axillaris }\end{array}$ & $\mathrm{Fr}$ & $x$ & $x$ & $x$ & 0.04 & $x$ & 1.58 & 0.11 & 0.83 & 0.04 & 0.67 & 0.06 & 0.16 & 0.68 & $x$ & $x$ & $x$ \\
\hline $\begin{array}{l}\text { Colocasia } \\
\text { antiquorum }\end{array}$ & L, Sh & 5.92 & 0.22 & 0.26 & 12 & $x$ & 227 & 10 & $x$ & $x$ & $x$ & $x$ & $x$ & $x$ & $x$ & $\mathrm{x}$ & $x$ \\
\hline Colocasis esculenta & U & $x$ & $x$ & $x$ & $x$ & $x$ & 19 & 1.1 & 1.7 & 1 & 340 & $x$ & $x$ & 28 & $x$ & $x$ & $x$ \\
\hline $\begin{array}{l}\text { Commelina } \\
\text { benghalensis }\end{array}$ & L, Sh & $x$ & $x$ & $x$ & $x$ & $x$ & $\begin{array}{c}1431.6 \\
\pm \\
6.41\end{array}$ & $\begin{array}{c}115.92 \\
\pm \\
5.51\end{array}$ & $\begin{array}{l}2.68 \pm \\
0.17\end{array}$ & $\begin{array}{c}200 \pm \\
7.02\end{array}$ & $\begin{array}{l}390 \pm \\
15.52\end{array}$ & $\begin{array}{c}2.72 \pm \\
0.09\end{array}$ & $x$ & $\begin{array}{c}220.8 \pm \\
4.15\end{array}$ & $\begin{array}{c}7.98 \pm \\
0.26\end{array}$ & $x$ & $x$ \\
\hline Crotalaria juncea & L, Sh & $x$ & $x$ & $x$ & $x$ & $x$ & 200 & $x$ & $x$ & $x$ & $x$ & $x$ & $x$ & $x$ & $x$ & $x$ & $x$ \\
\hline $\begin{array}{l}\text { Dendrocalamus } \\
\text { strictus }\end{array}$ & L, Sh & $x$ & $x$ & $x$ & 2.43 & 0.58 & 139.5 & 2.91 & $x$ & 0.08 & $x$ & $x$ & 58.13 & 0.17 & $x$ & $x$ & $x$ \\
\hline
\end{tabular}


TABLE 6 | Continued

\begin{tabular}{|c|c|c|c|c|c|c|c|c|c|c|c|c|c|c|c|c|c|}
\hline Edible species & Parts & Vit A & Vit B1 & Vit B2 & Vit C & Vit E & $\mathrm{Ca}$ & $\mathrm{Fe}$ & $\mathrm{Zn}$ & $\mathrm{Na}$ & $\mathbf{K}$ & $\mathrm{Cu}$ & $\mathbf{P}$ & $\mathrm{Mg}$ & Mn & $\mathrm{Se}$ & Folic acid \\
\hline Dioscorea bulbifera & U & 0.3 & $x$ & $x$ & 4 & $x$ & 20 & 4.09 & 0.38 & 0.08 & $x$ & $x$ & $x$ & $x$ & $x$ & $x$ & 0.028 \\
\hline $\begin{array}{l}\text { Diospyros } \\
\text { melanoxylon }\end{array}$ & $\mathrm{Fr}$ & 0.361 & 0.01 & 0.04 & 1 & $x$ & 60 & 0.5 & $x$ & $x$ & $x$ & $x$ & $x$ & $x$ & $x$ & $x$ & $x$ \\
\hline Diplazium esculentum & $\mathrm{Fr}$ & $x$ & $x$ & $x$ & $x$ & $x$ & 1.02 & 0.56 & 0.58 & 0.08 & 2.37 & 0.04 & 0.5 & 0.51 & $x$ & $x$ & $x$ \\
\hline $\begin{array}{l}\text { Diploknema } \\
\text { butyracea }\end{array}$ & $\mathrm{Fr}$ & $\mathrm{x}$ & $x$ & $x$ & 0.03 & $x$ & 0.82 & 0.18 & 0.86 & 0.07 & 0.82 & 0.04 & 0.09 & 0.61 & $x$ & $\mathrm{x}$ & $x$ \\
\hline Elaeagnus latifolia & $\mathrm{Fr}$ & $x$ & $x$ & $\mathrm{x}$ & 0.07 & $\mathrm{x}$ & 1.47 & 0.18 & 1.19 & 0.05 & 0.91 & 0.05 & 0.09 & 0.54 & $\mathrm{x}$ & $x$ & $x$ \\
\hline $\begin{array}{l}\text { Elaeagnus } \\
\text { rhamnoides }\end{array}$ & $\mathrm{Fr}$ & $x$ & $x$ & $x$ & 0.26 & $x$ & 0.17 & 0.06 & 0.88 & $x$ & $x$ & 0.02 & 0.31 & 0.31 & $x$ & $x$ & $x$ \\
\hline $\begin{array}{l}\text { Elaeocarpus } \\
\text { sikkimensis }\end{array}$ & $\mathrm{Fr}$ & $x$ & $x$ & $x$ & 0.01 & $x$ & 0.63 & 0.15 & 0.64 & 0.04 & 1.01 & 0.08 & 0.07 & 0.35 & $x$ & $x$ & $x$ \\
\hline Ensete superbum & $\mathrm{FI}$ & $x$ & $x$ & $x$ & $x$ & $x$ & $\begin{array}{c}665.6 \pm \\
5.94\end{array}$ & $\begin{array}{c}518.4 \pm \\
11.06\end{array}$ & $\begin{array}{c}3.78 \pm \\
0.15\end{array}$ & $\begin{array}{c}600 \pm \\
4.58\end{array}$ & $\begin{array}{c}180 \pm \\
6.11\end{array}$ & $\begin{array}{c}4.46 \pm \\
0.15\end{array}$ & $x$ & $\begin{array}{c}176.8 \pm \\
4.86\end{array}$ & $\begin{array}{c}11.74 \pm \\
0.46\end{array}$ & $\mathrm{x}$ & $x$ \\
\hline Enydra fluctuans & $\mathrm{L}, \mathrm{Sh}$ & 0.98 & 0.96 & $x$ & 4 & $x$ & 246 & 16.99 & 0.94 & 80 & $x$ & $x$ & $x$ & $x$ & $x$ & $x$ & 0.096 \\
\hline Euphorbia granulata & $\mathrm{L}, \mathrm{Sh}$ & 11.68 & 3.07 & $x$ & 9 & $x$ & 425 & 81.09 & 1.01 & 24.9 & $x$ & $x$ & $x$ & $x$ & $x$ & $x$ & 0.072 \\
\hline Ficus bengalenis & $\mathrm{Fr}$ & $x$ & $x$ & $x$ & $x$ & $x$ & 364 & $x$ & $x$ & $x$ & $x$ & $x$ & $x$ & $x$ & $x$ & $x$ & $x$ \\
\hline Ficus geniculata & L, Sh & 0.53 & $x$ & $x$ & 5 & $x$ & 672 & 8.89 & 4.63 & 11.3 & $x$ & $x$ & $x$ & $x$ & $x$ & $x$ & 0.012 \\
\hline Ficus racemosa & Bark & $x$ & $x$ & $x$ & $x$ & $x$ & 172.9 & 15.92 & 0.05 & 25.5 & 1197.5 & 0.52 & $x$ & 19.62 & 0.19 & $x$ & $x$ \\
\hline Ficus sp. & L, Sh & 8.2 & $x$ & $x$ & $x$ & $x$ & 295 & 2.77 & 0.8 & 7.5 & $x$ & $x$ & $x$ & $x$ & $x$ & $x$ & 0.039 \\
\hline Hibiscus cannabinus & $\mathrm{L}, \mathrm{Sh}$ & 6.97 & 0.07 & 0.39 & 20 & $x$ & 172 & 2.28 & 0.27 & $x$ & $x$ & $x$ & $x$ & $x$ & $x$ & $x$ & $x$ \\
\hline Ipomoea aquatica & L, Sh & 1.98 & 0.05 & 0.13 & 37 & $x$ & 110 & 3.9 & $x$ & $x$ & $x$ & $x$ & $x$ & $x$ & $x$ & $x$ & $x$ \\
\hline Kaempferia galanga & $U$ & $x$ & $x$ & $x$ & $x$ & $x$ & 950 & 69.91 & 8.35 & 0.32 & 12.23 & 0.91 & 60 & 293.92 & 42.65 & 0.0012 & $x$ \\
\hline Leucas cephalotes & L, Sh & 18.46 & $x$ & $x$ & 8 & $x$ & 236 & 20.02 & 0.8 & 10.6 & $x$ & $x$ & $x$ & $x$ & $x$ & $x$ & 0.01 \\
\hline Madhuca neriifolia & $\mathrm{Fr}$ & 0.307 & $x$ & $x$ & 40 & $x$ & 45 & 0.23 & $x$ & $x$ & $x$ & $x$ & $x$ & $x$ & $x$ & $x$ & $x$ \\
\hline Marsilea minuta & $\mathrm{L}, \mathrm{Sh}$ & $x$ & $x$ & $x$ & $x$ & $x$ & 53 & $x$ & $x$ & $x$ & $x$ & $x$ & $x$ & $x$ & $x$ & $x$ & $x$ \\
\hline Meyna spinosa & L, Sh & $x$ & $x$ & $x$ & $x$ & $x$ & 127 & $x$ & $x$ & $x$ & $x$ & $x$ & $x$ & $x$ & $x$ & $x$ & $x$ \\
\hline Moringa oleifera & $\mathrm{L}, \mathrm{Sh}$ & 6.78 & 0.06 & 0.05 & 220 & $x$ & 440 & 0.85 & 0.16 & $x$ & $x$ & $x$ & $x$ & $x$ & $x$ & $x$ & $x$ \\
\hline Moringa oleifera & $\mathrm{Fr}$ & $x$ & $x$ & $x$ & $x$ & $x$ & 51 & $x$ & $x$ & $x$ & $x$ & $x$ & $x$ & $x$ & $x$ & $x$ & $x$ \\
\hline Nelumbo nucifera & Se & $x$ & 0.22 & 0.01 & 3.94 & 0.46 & 44.5 & 1.3 & 1.3 & 3.3 & 1630 & 1 & $x$ & 165 & 5.7 & $x$ & $x$ \\
\hline Nymphaea nouchali & $\mathrm{L}, \mathrm{Sh}$ & $x$ & $x$ & $x$ & $x$ & $x$ & $\begin{array}{c}379.54 \\
\pm \\
0.58\end{array}$ & $\begin{array}{c}3.59 \pm \\
0.09\end{array}$ & $\begin{array}{c}3.63 \pm \\
0.13\end{array}$ & $\begin{array}{c}643.58 \\
\pm \\
0.82\end{array}$ & $\begin{array}{c}858.39 \\
\pm \\
0.68\end{array}$ & $\begin{array}{c}1.77 \pm \\
0.11\end{array}$ & $x$ & $\begin{array}{c}145.48 \\
\pm \\
1.11\end{array}$ & $x$ & $x$ & $x$ \\
\hline Nymphaea rubra & U & $x$ & $x$ & $x$ & $\begin{array}{c}14.43 \pm \\
0.03\end{array}$ & $x$ & $\begin{array}{c}354.1 \pm \\
018\end{array}$ & $\begin{array}{c}28.14 \pm \\
0.24\end{array}$ & $\begin{array}{c}1.64 \pm \\
0.01\end{array}$ & $\begin{array}{c}34.1 \pm \\
0.36\end{array}$ & $\begin{array}{c}734 \pm \\
0.74\end{array}$ & $\begin{array}{c}1.12 \pm \\
0.01\end{array}$ & $x$ & $\begin{array}{c}104 \pm \\
0.06\end{array}$ & $\begin{array}{c}1.34 \pm \\
0.01\end{array}$ & $x$ & $x$ \\
\hline Oxalis corniculata & L, Sh & $x$ & $x$ & $x$ & 21 & $x$ & 234 & 14.75 & $x$ & $x$ & $x$ & $x$ & $x$ & $x$ & $x$ & $x$ & $x$ \\
\hline Phyllanthus emblica & $\mathrm{Fr}$ & $x$ & $x$ & $x$ & $x$ & $\mathrm{x}$ & 27.6 & 3.3 & 1.8 & 4.2 & 282.0 & 0.28 & 28.2 & 11.8 & 1.1 & 0.24 & $x$ \\
\hline Polygonum molle & $\mathrm{Fr}$ & $x$ & $x$ & $x$ & $x$ & $x$ & 0.15 & 0.32 & 0.28 & 0.09 & 2.02 & 0.06 & 0.27 & 0.43 & $x$ & $x$ & $x$ \\
\hline
\end{tabular}


TABLE 6 | Continued

\begin{tabular}{|c|c|c|c|c|c|c|c|c|c|c|c|c|c|c|c|c|c|}
\hline Edible species & Parts & Vit A & Vit B1 & Vit B2 & Vit C & Vit E & $\mathrm{Ca}$ & $\mathrm{Fe}$ & $\mathrm{Zn}$ & $\mathrm{Na}$ & $\mathbf{K}$ & $\mathrm{Cu}$ & $\mathbf{P}$ & Mg & Mn & Se & Folic acid \\
\hline Polygonum plebeium & L, Sh & $x$ & $x$ & $x$ & $x$ & $x$ & 194 & $x$ & $x$ & $x$ & $x$ & $x$ & $x$ & $x$ & $x$ & $x$ & $x$ \\
\hline Portulaca oleracea & L, Sh & $x$ & $x$ & $x$ & 15 & $x$ & 227 & 16.17 & $x$ & $x$ & $x$ & $x$ & $x$ & $x$ & $x$ & $x$ & $x$ \\
\hline Prunus cerasoides & $\mathrm{Fr}$ & $\mathrm{x}$ & $x$ & $\mathrm{x}$ & 0.32 & $x$ & 0.2 & 0.21 & 0.2 & 0.02 & 0.47 & 0.01 & 0.18 & 0.59 & $\mathrm{x}$ & $x$ & $\mathrm{x}$ \\
\hline Prunus napaulensis & $\mathrm{Fr}$ & $x$ & $x$ & $x$ & 608.9 & $x$ & 1220 & 10.7 & 1.49 & 0.1 & 16.5 & 1.22 & 70 & 217.74 & 6.62 & 0.0005 & $x$ \\
\hline Quercus robur & $\mathrm{Fr}$ & $x$ & $x$ & $x$ & $x$ & $x$ & 410 & 4.7 & 1.59 & 0.13 & 8.3 & 1.66 & 150 & 126 & 5.63 & 0.0002 & $x$ \\
\hline Rhus chinensis & $\mathrm{Fr}$ & $x$ & $x$ & $x$ & $x$ & $x$ & 1020 & 4.17 & 2.37 & 0.03 & 8.41 & 0.63 & 160 & 111.1 & $x$ & 0.0009 & $x$ \\
\hline Schleichera trijuga & $\mathrm{Fr}$ & $x$ & $x$ & $x$ & $x$ & $x$ & 15 & $x$ & $x$ & $x$ & $x$ & $x$ & $x$ & $x$ & $x$ & $x$ & $x$ \\
\hline $\begin{array}{l}\text { Semecarpus } \\
\text { anacardium }\end{array}$ & $\mathrm{Fr}$ & $x$ & $x$ & $x$ & $x$ & $x$ & 295 & 6.1 & $x$ & $x$ & $x$ & $x$ & $x$ & $x$ & $x$ & $x$ & $x$ \\
\hline Senna tora & L, Sh & 10.512 & 0.08 & 0.19 & 82 & $x$ & 520 & 12.4 & $x$ & $x$ & $x$ & $x$ & $x$ & $x$ & $x$ & $x$ & $x$ \\
\hline Solanum torvum & L, Sh & 0.078 & $x$ & $x$ & 2.686 & $x$ & 22.15 & 7.68 & 2.14 & $x$ & $x$ & 0.26 & $x$ & $x$ & 1.95 & $x$ & $x$ \\
\hline Spondia pinnata & $\mathrm{Fr}$ & $\mathrm{x}$ & $x$ & $x$ & $x$ & $x$ & 0.93 & $\begin{array}{c}1.32 \pm \\
0.02\end{array}$ & $x$ & $\begin{array}{c}1.54 \pm \\
0.01\end{array}$ & $\begin{array}{c}1.38 \pm \\
0.80\end{array}$ & $\begin{array}{c}1.23 \pm \\
0.03\end{array}$ & $\begin{array}{c}0.68 \pm \\
0.01\end{array}$ & $x$ & $x$ & $x$ & $x$ \\
\hline Tamarindus indica & $\mathrm{Fr}$ & $x$ & $x$ & $x$ & $x$ & $x$ & $\begin{array}{c}248.56 \\
\pm \\
1.3\end{array}$ & $\begin{array}{c}7.14 \pm \\
0.92\end{array}$ & $\begin{array}{c}6.94 \pm \\
0.51\end{array}$ & $\begin{array}{c}28.83 \pm \\
1.34\end{array}$ & $\begin{array}{c}1315.28 \\
\pm \\
5.74\end{array}$ & $\begin{array}{c}0.59 \pm \\
0.16\end{array}$ & $\begin{array}{c}369.47 \\
\pm \\
2.14\end{array}$ & $\begin{array}{c}285.14 \\
\pm \\
2.82\end{array}$ & $\begin{array}{c}0.81 \pm \\
0.12\end{array}$ & $x$ & $\mathrm{x}$ \\
\hline Terminalia chebula & $\mathrm{Fr}$ & $x$ & $x$ & $x$ & $x$ & $x$ & 0.81 & 0.03 & 0.44 & 0.08 & 1.27 & 0.04 & 0.04 & 0.3 & $\mathrm{x}$ & $x$ & $\mathrm{x}$ \\
\hline $\begin{array}{l}\text { Trianthema } \\
\text { portulacastrum }\end{array}$ & $\mathrm{L}, \mathrm{Sh}$ & $x$ & $x$ & $x$ & 70 & $x$ & 100 & 38.5 & $x$ & $x$ & $x$ & $x$ & $x$ & $x$ & $x$ & $x$ & $x$ \\
\hline Urtica dioica & $\mathrm{Fr}$ & $x$ & $x$ & $x$ & $x$ & $x$ & 1.31 & 1.31 & $x$ & 0.07 & 1.87 & $x$ & 0.27 & 0.42 & $x$ & $x$ & $x$ \\
\hline Viburnum corylifolium & $\mathrm{Fr}$ & $x$ & $x$ & $x$ & 238.7 & $x$ & 630 & 3.55 & 1.62 & 0.11 & 11.13 & 1.27 & 140 & 161.39 & 9.63 & 0.0002 & $\mathrm{x}$ \\
\hline Vicia hirsuta & L, Sh & 0.55 & $x$ & $x$ & 23 & $x$ & 215 & 7.78 & 4.11 & 33.18 & $x$ & $x$ & $x$ & $x$ & $x$ & $X$ & 0.07 \\
\hline Zanthoxylum rhetusa & $\mathrm{Fr}$ & $\mathrm{x}$ & $x$ & $\mathrm{x}$ & $\mathrm{x}$ & $x$ & 0.88 & 0.05 & 1.16 & 0.02 & 0.72 & 0.12 & 0.14 & 0.35 & $\mathrm{x}$ & $x$ & $\mathrm{x}$ \\
\hline Ziziphus jujuba & $\mathrm{Fr}$ & 0.21 & 0.02 & 0.05 & 76 & $x$ & 4 & 0.5 & 0.1 & $x$ & $x$ & $x$ & $x$ & $x$ & $x$ & $x$ & $x$ \\
\hline
\end{tabular}

Vit A, Vitamin A; Vit B1, Vitamin B1; Vit C, Vitamin C; Ca, Calcium; Fe, Iron; Zn, Zinc; Na, Sodium; K, Potassium; Mg, Magnesium; Mn, Manganese; Se- Selenium; Cu, Copper; P, Phosphorous. L; Sh, leafy shoots/ shoots/ leaves; Fr, Fruits; Fl, Flowers; Se, Seeds; U, underground parts; roots/tuber

Wills et al., 1983; Barthakur and Arnold, 1991; Callaway, 2004; Pugalenthi et al., 2004; Sheela et al., 2004; Rathore, 2009; Ahmed et al., 2010; Andola and Purohit, 2010; Mohan and Kalidass, 2010; Mahadkar et al., 2012; Akoto et al., 2015; Zhang et al., 2015; Satter et al., 2016; Mishra et al., 2018). 

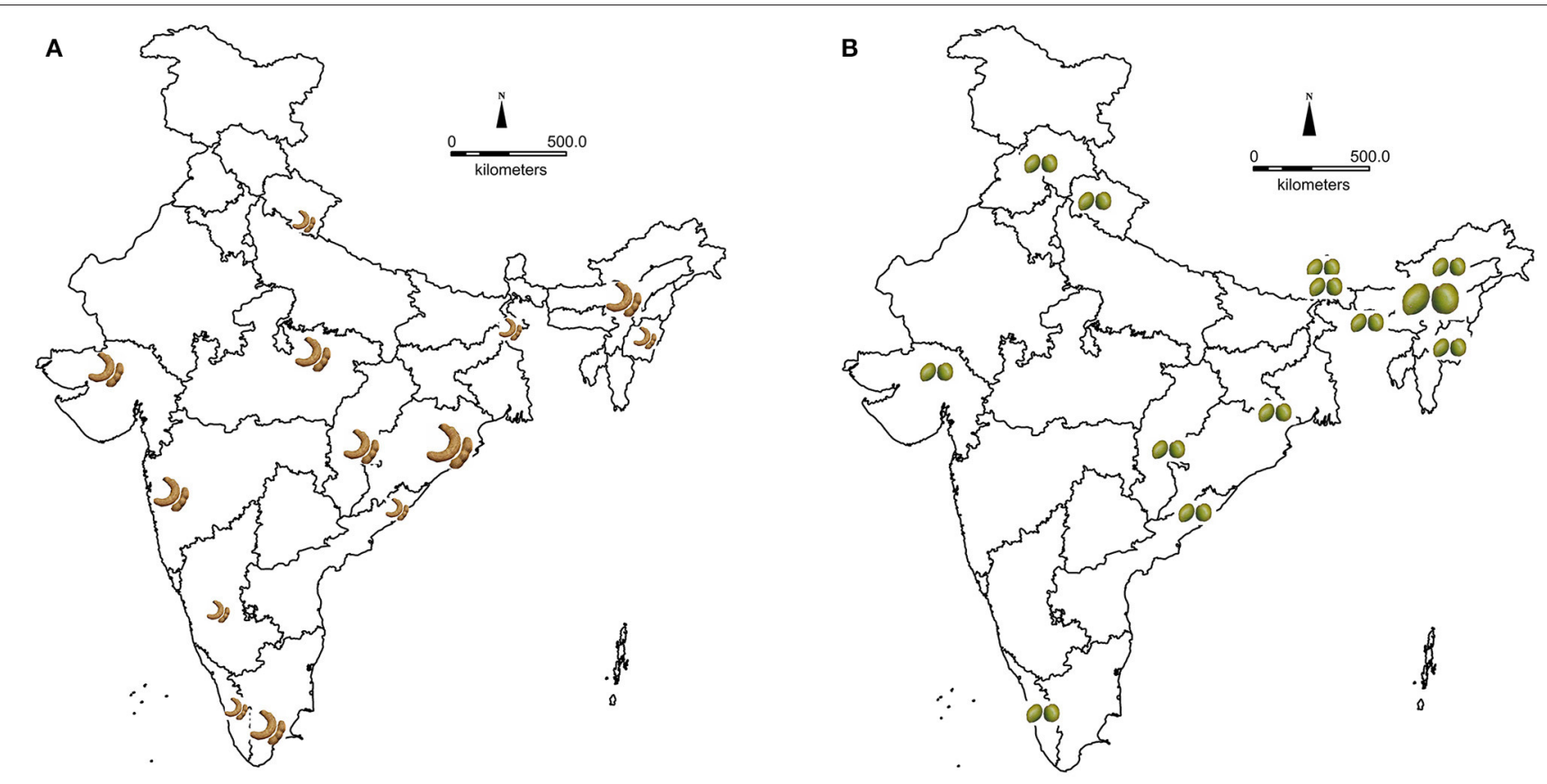

C

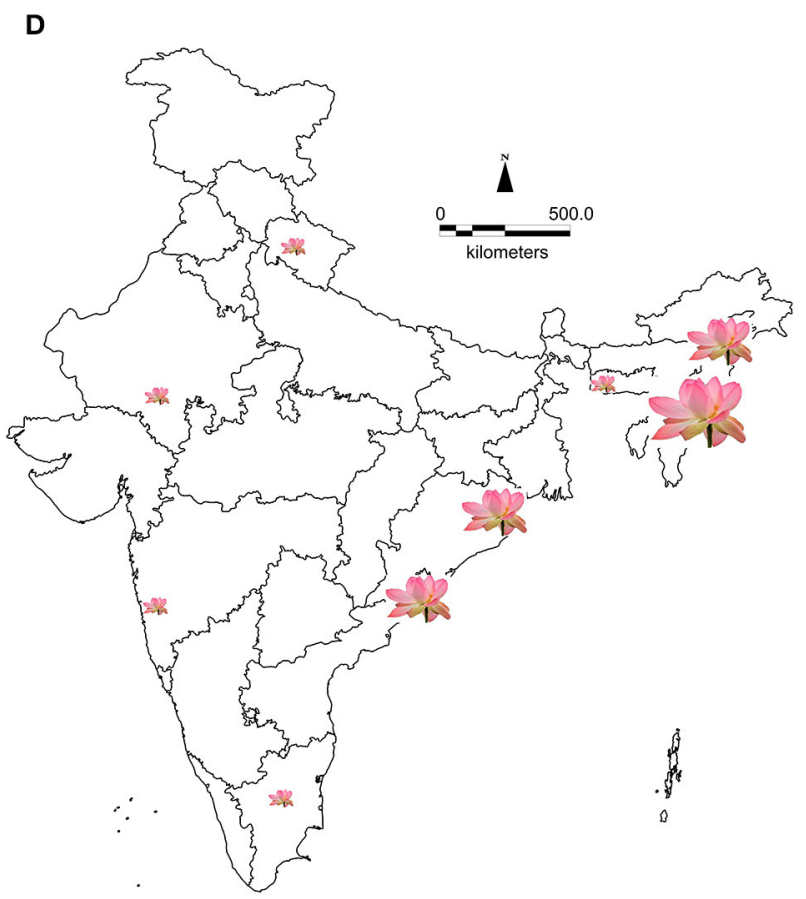

FIGURE $\mathbf{5}$ | Spatial distribution of a few prioritized species: species with higher RFC and RUV (dots represent spatial distribution and dot size is proportional to the number of plant part use) - (A) Tamarindus indica and (B) Spondias pinnata; species with higher RFC (dots represent spatial distribution and dot size is proportional to the number of papers cited from the area) (C) Oxalis corniculata; and species with higher use value (dots represent spatial distribution and dot size is proportional to the number of plant part use) (D) Nelumbo nucifera.

policy formulation. Our analyses have selected a small subset from the 1,400 edible species on the basis of their high RFC and RUV values. The indices stand for the easy availability, greater accessibility, and relatively wider acceptance among people residing in distant geographic regions and therefore these attributes justify their inclusion into the prioritization and 
policy formation. For example, the ubiquity of Oxalis corniculata, Amaranthus spinosus, Solanum americanum, Centella asiatica, Alternanthera sessilis, and Ipomoea aqautica, etc., indicates their easy procuring and cross-cultural assimilation. On the other hand, species such as Nymphaea nouchali, N. rubra, Nelumbo nucifera, Cannabis sativa, Tamarindus indica, Spondias pinnata, and Dregea volubilis also represent a high degree of usability for their use of three or even more parts (Figures 5A-D). Several reports have explicitly highlighted their nutritional benefits in terms of vitamins and minerals (Table 6). So, these prioritized plants deserve the attention of researchers, policymakers, and farmers to be integrated toward a sustainable food system. In the absence of appropriate policy, it could remain localized and may not widely exert its beneficial effect on nutritional security. Moreover, many were already well-assimilated into local or regional food culture, but have been eroded over time, and could be resurrected through a promotion to sensitize consumers and would gain momentum with policy in place.

\section{CONCLUSION}

It has largely been recognized that food security is ensured when all people have access to sufficient and nutritious food (World Food Summit, 1996). Nutritious food relates to dietary quality and diversity that are indicators of an adequate amount of micro-nutrients in the diet (World Health Organization, 2008; Royal Society, 2009; FAO and FHI 360, 2016). Yet strategies for ensuring food security often advocate for an intensified agriculture that focusses on the enhanced production of major cereals only (FAO, 2012; Jones, 2017), but remaining quite blind to dietary diversity, thus disrupting healthy food systems (Pingali, 2015). While there is a consensus that wild uncultivated foods cannot entirely erase the gap between supply and demand, the researchers underscore that the difference between supply and demand would be much wider if wild food was absent from our food system (Bharucha and Pretty, 2010).

Our study uncovered a great majority of WEP from nearly two hundred families has been consumed regularly around India. Various parts, leafy shoots, fruits, flowers, seeds, or underground organs are generally included in the food repertoire. Procured

\section{REFERENCES}

Agrahar-Murugkar, D., and Subbulakshmi, G. (2005). Nutritive values of wild edible fruits, berries, nuts, roots and spices consumed by the Khasi tribes of India. Ecol. Food Nutr. 44, 207-223. doi: 10.1080/03670240590 953025

Ahmed, F., Asha, M. R., Urooj, A., and Bhat, K. K. (2010). Ficus racemosa bark: nutrient composition, physicochemical properties and its utilization as nutra tea. Int. J. Nutr. Metab. 2, 033-039.

Ajesh, T. P., Naseef, S. A., and Kumuthakalavalli, R. (2012). Ethnobotanical documentation of wild edible fruits used by muthuvan tribes of Idukki, KeralaIndia. Int. J. Pharm. BioSci. 3, 479-487.

Akoto, O., Borquaye, L. S., Howard, A. S., and Konwuruk, N. (2015). Nutritional and mineral composition of the fruits of Solanum torvum from Ghana. Int. J.Chem. Biomol. Sci. 1, 222-226. from anthropogenic landscapes, many of these have crosscultural acceptance and are valued for their specific organ, while many are important for their multi-part usage; they can be prioritized for policy decisions. The diversity of edible flora, their multifarious usage across various cultural geographic regions, and wider mentions, strongly suggest the fact that the practice of eating from the wild has been an age-old exercise. This practice may have eroded over time but could be resurrected with the proper framework, policy, and information dissemination. It is also imperative to shift our focus from a small subset of plants and embrace a diverse food base in order to enrich our dietary quality. Additionally, a diverse resource base would enable our food system to be more resilient in the face of climatic changes.

\section{DATA AVAILABILITY STATEMENT}

The datasets generated for this study could be available from the corresponding author on request with proper justification and on mutual agreement.

\section{AUTHOR CONTRIBUTIONS}

AR and RR designed the study, collected, compiled, and analyzed the data. ES helped in data collection. AR and RR wrote the manuscript with inputs from ES.

\section{ACKNOWLEDGMENTS}

We acknowledge the informal discussions with Abhra Chakraborty, Rakesh Mitra, and Sumit Sarkar in various stages of the study. We would like to thank Rahul Mukherjee and Karen Meehan for language editing and three reviewers for their suggestions. We received no funding for this study.

\section{SUPPLEMENTARY MATERIAL}

The Supplementary Material for this article can be found online at: https://www.frontiersin.org/articles/10.3389/fsufs. 2020.00056/full\#supplementary-material
Albuquerque, U. P., Soldati, G. T., Ramos, M. A., de Melo, J. G., de Medeiros, P. M., Nascimento, A. L. B., et al. (2015). "The influence of the environment on natural resource use: evidence of apparency," in Evolutionary Ethnobiology, eds U. Albuquerque, P. De Medeiros, A. Casas (Cham: Springer), 131-147. doi: 10.1007/978-3-319-19917-7_10

Anderson, E. N., Pearsall, D. M., Hunn E. S., and Turner, N. J. (eds.). (2011). Ethnobiology. Hoboken, NJ: John Wiley \& Sons, Inc. doi: 10.1002/9781118015872

Andola, H. C., and Purohit, V. K. (2010). Evaluation of nutritive and mineral value in ripe fruits of Spondias pinnata from two location of Western Himalaya, India. Med. Plants 2, 233-236. doi: 10.5958/j.0975-4261. 2.3.037

Angami, A., Gajurel, P. R., Rethy, P., Singh, B., and Kalita, S. K. (2006). Status and potential of wild edible plants of Arunachal Pradesh. Indian J. Tradit. Know. $5,541-550$ 
Angelsen, A., Jagger, P., Babigumira, R., Belcher, B., Hogarth, N. J., Bauch, S., et al. (2014). Environmental income and rural livelihoods: a global-comparative analysis. World Dev. 64(Suppl. 1), S12-S28. doi: 10.1016/j.worlddev.2014.03.006

Arinathan, V., Mohan, V. R., Britto, A., and Murugan, C. (2007). Wild edibles used by Palliyars of the western Ghats, Tamil Nadu. Indian J. Tradit. Know. 6, 163-168

Ayyanar, M., and Ignacimuthu, S. (2005). Traditional knowledge of Kani tribals in Kouthalai of Tirunelveli hills, Tamil Nadu, India. J. Ethnopharmacol. 102, 246-255. doi: 10.1016/j.jep.2005.06.020

Barthakur, N. N., and Arnold, N. P. (1991). Chemical analysis of the emblic (Phyllanthus emblica L.) and its potential as a food source. Sci. Hortic. 47, 99-105. doi: 10.1016/0304-4238(91)90031-S

Barua, P. T., and Tomar, R. S. (2014). Role of genus cassia in combating malnutrition in Sahariya dominated Sheopur kalan region of Madhya Pradesh. Int. J. Sci. Res. 3, 868-872

Bedi, S. J. (1978). Ethnobotany of the Ratan Mahal Hills, Gujarat, India. Econ. Bot. 32, 278-284. doi: 10.1007/BF02864701

Behera, K. K., Mishra, N. M., Dhal, N. K., and Rout, N. C. (2008). Wild edible plants of Mayurbhanj district, Orissa, India. J.f Econ. Taxon. Bot. 32, 305-314.

Berkes, F. (ed.). (2009). Sacred Ecology: Traditional Ecological Knowledge and Resource Management. 2nd edn. Philadelphia (PA): Taylor and Francis.

Bharucha, Z., and Pretty, J. (2010). The roles and values of wild foods in agricultural systems. Phil. Trans. R. Soc. B. 365, 2913-2926. doi: 10.1098/rstb.2010.0123

Bhatt, B. P., Singh, K., and Singh, A. (2005). Nutritional values of some commercial edible bamboo species of the North Eastern Himalayan region, India. J. Bamboo Rattan 4, 111-124. doi: 10.1163/1569159054699317

Binu, S. (2010). Wild edible plants used by the tribals in Pathanamthitta district, Kerala. Indian J. Tradit. Know. 9, 309-312

Biswas, K., and Das, A. P. (2011). "Documentation of wild leafy vegetables from the tribal dominated parts of Malda District of Paschimbanga, India," in Recent Studies in Biodiversity and Traditional Knowledge in India eds. C. Ghosh and A. P. Das (Malda: Gour College), 301-306.

Broegaard, R. B., Rasmussen, L. V., Dawson, N., Mertz, O., Vongvisouk, T., and Grogan, K. (2017). Wild food collection and nutrition under commercial agriculture expansion in agriculture-forest landscapes. For. Policy Econ. 84, 92-101. doi: 10.1016/j.forpol.2016.12.012

Callaway, J. C. (2004). Hempseed as a nutritional resource: an overview. Euphytica 140, 65-72. doi: 10.1007/s10681-004-4811-6

Chaithanya, V. V., Sugiya, N., and Aneesh, K. S. (2015). Wild edible plants traditionally used by Kadar tribes of Vazhachal forest division, Thrissur, Kerala. J. Glob. Biosci. 4, 3344-3349.

Chand, R., Singh, A. N., and Nirmala C. (2017). Ethnoecological survey of underutilized plant diversity of Hamirpur district, Himachal Pradesh, India: an edibility assessment. Environ. Ecol. Res. 5, 13-29. doi: 10.13189/eer.2017.050101

Chauhan, D., Shrivastava, A. K., and Patra, S. (2014). Diversity of leafy vegetables used by tribal peoples of Chhattisgarh, India. Int. J. Curr. Microbiol. Appl. Sci. 3, 611-622.

Chauhan, S. H., Yadav, S., Takahashi, T., Luczaj, L., D’Cruz, L., and Okada, K. (2018). Consumption patterns of wild edibles by the vasavas: a case study from Gujarat, India. J. Ethnobiol. Ethnomed. 14:57. doi: 10.1186/s13002-0180254-3

Chevalier, A., Marinova, E, and Peña-Chocarro L. (eds). (2014a). Plants and People: Choices and Diversity Through Time (Vol. 1). Oxford, UK: Oxbow Books.

Chevalier, A., Marinova, E., and Peña-Chocarro, L. (2014b). "Factors and issues in plant choice," in Plants and People: Choices and Diversity Through Time. Vol. 1. eds A. Chevalier, E. Marinova, and L. Peña-Chocarro (Oxford; Philadelphia: Oxbow Books), 3-12. doi: 10.2307/j.ctvhldwfp

Chorol, S., Angchok, D., Angmo, P., Tamchos, T., and Singh, R. K. (2018). Traditional knowledge and heirloom root vegetables: food security in transHimalayan Ladakh, India. Indian J. Tradit. Knowl. 17, 191-197

Choudhary, K., Singh, M., and Pillai, U. (2008). Ethnobotanical survey of Rajasthan-an update. Am. Eurasian J. Bot. 1, 38-45.

Christiensen, H. (2002). Ethnobotany of the Iban and the Kelabit. Videbaek: Joint Publication of Forest Department Sarawak, NEPCon and University of Aarhus Cook, J. A., VanderJagt, D. J., Pastuszyn, A., Mounkaila, G., Glew, R. S., Millson, M., et al. (2000). Nutrient and chemical composition of 13 wild plant foods of Niger. J. Food Composit. Anal.13, 83-92. doi: 10.1006/jfca.19 99.0843

Cruz-García, G. S. (2006). The mother-child nexus. Knowledge and valuation of wild food plants in Wayanad, Western Ghats, India. J. Ethnobiol. Ethnomed. 2:39. doi: 10.1186/1746-4269-2-39

Cruz-Garcia, G. S., and Ertug, F. (2014). "Introduction: wild food plants in the present and past," in Plants and People. Choices and Diversity Through Time, eds A. Chevalier, E. Marinova and L. Peña-Chocarro (Oxford: Oxbow Books), 211-215.

Cruz-Garcia, G. S., and Price, L. L. (2011). Ethnobotanical investigation of 'wild' food plants used by rice farmers in Kalasin, Northeast Thailand. J. Ethnobiol. Ethnomed. 7:33. doi: 10.1186/1746-4269-7-33

Cruz-Garcia, G. S., and Price, L. L. (2012). Weeds as important vegetables for farmers. Acta Soc. Bot. Pol. 81, 397-403. doi: 10.5586/asbp.2012.047

Devi, M. H., Singh, P. K., and Choudhury, M. D. (2014). Income generating plants of Keibul Lamjao National Park, Loktak Lake, Manipur and man-animal conflicts. Pleione 8, 30-36.

Devi, M. R., and Salam, S. (2016). Wild edible plants used by the Monsang Naga tribe of Manipur, India. Pleione 10, 90-96.

Devi, O. S., Komor, P., and Das, D. (2010). A checklist of traditional edible bioresources from Ima markets of Imphal Valley, Manipur, India. J. Threat. Taxa 2, 1291-1296. doi: 10.11609/JoTT.o2256.1291-6

Dewey, K. G. (1981). Nutritional consequences of the transformation from subsistence to commercial agriculture in Tabasco, Mexico. Hum. Ecol. 9, 151-187. doi: 10.1007/BF00889132

Dogan, Y., Ugulu, I., and Durkan, N. (2013). Wild edible plants sold in the local markets of Izmir, Turkey. Pak. J. Bot. 45, 177-184.

Ertug, F. (2014). "Wild plant food: routine dietary supplement or famine food?" in Plants and People. Choices and Diversity Through Time, eds A. Chevalier, E. Marinova, and L. Peña-Chocarro (Oxford: Oxbow Books), 211-215.

Ezell, K. C., Pearsall, D. M., and Zeidler, J. A. (2006). Root and tuber phytoliths and starch grains document manioc (Manihot esculenta) arrowroot (Maranta arundinacea) and llerén (Calathea sp.) at the real alto site ecuador. Econ. Bot. 60, 103-120. doi: 10.1663/0013-0001(2006)60[103:RATPAS]2.0.CO;2

FAO (2010). The Second Report on the State of the World's Plant Genetic Resources for Food and Agriculture. Rome: Food and Agriculture Organization of the United Nations.

FAO (2012). The State of Food Insecurity in the World: Economic Growth is Necessary But Not Sufficient to Accelerate Reduction of Hunger and Malnutrition. Italy: Food and Agriculture Organization of the United Nations.

FAO, and FHI 360 (2016). Minimum Dietary Diversity for Women: A Guide for Measurement. Rome.

FAO, WFP, and IFAD (2012). The State of Food Insecurity in the World 2012 Economic Growth is Necessary but Not Sufficient to Accelerate Reduction of Hunger and Malnutrition. Rome: FAO.

Fatma, N., and Pan, T. K. (2012). Checklist of wild edible plants of Bihar, India. Our Nat. 10, 233-241. doi: 10.3126/on.v10i1.7785

Fowler, C., and Mooney, P. (1990). The Threatened Gene: Food, Politics, and the Loss of Genetic Diversity. Cambridge: Lutterworth Press.

Gangte, H. E., Thoudam, N. S., and Zomi, G. T. (2013). Wild edible plants used by the Zou tribe in Manipur, India. Int. J. Sci. Res. Pub. 3, 1-8.

Ghatapanadi, S. R., Johnson, N., and Rajasab, A. H. (2011). Documentation of folk knowledge on medicinal plants of Gulbarga district, Karnataka. Indian. J. Tradit. Know. 10, 349-353.

Ghosh-Jerath, S., Singh, A., Kamboj, P., Goldberg, G., and Magsumbol, M. S. (2015). Traditional knowledge and nutritive value of indigenous foods in the oraon tribal community of Jharkhand: an exploratory crosssectional study. Ecol. Food Nutr. 54, 493-519. doi: 10.1080/03670244.2015.10 17758

Ghosh-Jerath, S., Singh, A., Magsumbol, M. S., Kamboj, P., and Goldberg, G. (2016). Exploring the potential of indigenous foods to address hidden hunger: nutritive value of indigenous foods of Santhal tribal community of Jharkhand, India. J. Hunger Environ. Nutr. 11, 548-568. doi: 10.1080/19320248.2016.1157545

González, J. A., García-Barriuso, M., and Amich, F. (2011). The consumption of wild and semi-domesticated edible plants in the Arribes del Duero (SalamancaZamora, Spain): an analysis of traditional knowledge. Genet. Resour. Crop Evol. 58, 991-1006. doi: 10.1007/s10722-010-9635-8 
Gosden, C., and Hather, J. G. (eds.). (2004). The Prehistory of Food: Appetites for Change. London: Routledge. doi: 10.4324/9780203 203385

Guralnik, J., Eisenstaedt, R. S., Ferrucci, L., Klein, H., and Woodman, R. (2004). Prevalence of anemia in persons 65 years and older in the United States: evidence for a high rate of unexplained anemia. Blood 104, 2263-2268 doi: 10.1182/blood-2004-05-1812

Hadjichambis, A. C., Paraskeva-Hadjichambi, D., Della, A., Elena Giusti, M., De Pasquale, C., Lenzarini, C., et al. (2008). Wild and semi-domesticated food plant consumption in seven circum-Mediterranean areas. Int. J. Food Sci. Nutr. 59, 383-414. doi: 10.1080/09637480701566495

Hama-Ba, F., Sibiria, N., Powell, B., Ickowitz, A., and Maundu, P. (2017). Micronutrient content of wild vegetable species harvested in forested and non-forested areas in Southwest Burkina Faso. For. Res. 6:213. doi: $10.4172 / 2168-9776.100213$

Harris, D. R., and Hillman, G. C. (2014). Foraging and Farming: the Evolution of Plant Exploitation. New York, NY: Routledge. doi: 10.4324/9781315746425

Horo, S., and Topno, S. (2015). Lesser known wild leafy vegetables consumed by "Ho" tribes of W. Singhbhum district, Jharkhand, India. J. Med. Plants $3,155-159$.

Hu, S. Y. (2005). Food Plants of China. Hongkong: The Chinese University Press.

Hunter, D., and Fanzo, J. (2013). "Introduction: agricultural biodiversity, diverse diets and improving nutrition," in Diversifying Food and Diets, eds J. Fanzo, D. Hunter, T. Borelli, and F. Mattei (New York, NY: Routledge), 33-46.

Ickowitz, A., Powell, B., Rowland, D., Jones, A., and Sunderland, T. C. H. (2019). Agricultural intensification, dietary diversity, and markets in the global food security narrative. Glob. Food Secur. 20, 9-16. doi: 10.1016/j.gfs.2018.11.002

Ickowitz, A., Rowland, D., Powell, B., Salim, M. A., and Sunderland, T. (2016). Forests, trees, and micronutrient-rich food consumption in Indonesia. PLoS ONE 11:e0154139. doi: 10.1371/journal.pone.0154139

Ignacimuthu, S., and Ayyanar, M. (2006). Ethnobotanical investigations among tribes in Madurai district of Tamil Nadu (India). J. Ethnobiol. Ethnomed. 2:25. doi: 10.1186/1746-4269-2-25

Jain, A., Singh, H. B., and Bhattacharyya, P. R. (2012). The ethnobotany and nutritional values of wild rice [Zizania latifolia (Griseb.) Turcz. ex Stapf] (Poaceae) in Manipur. Indian J. Tradit. Know. 11, 66-69

Jain, A., Sundriyal, M., Roshnibala, S., Kotoky, R., Kanjilal, P. B., Singh, H. B., et al. (2011). Dietary use and conservation concern of edible wetland plants at indoburma hotspot: a case study from northeast India. J. Ethnobiol. Ethnomed. 7:29. doi: $10.1186 / 1746-4269-7-29$

Jain, A. K., and Tiwari, P. (2012). Nutritional value of some traditional edible plants used by tribal communities during emergency with reference to Central India. Indian J. Tradit. Know. 11, 51-57

Jain, S. K. (1964). Wild plant foods of the tribals of Bastar. Khadi Gramodyog $10,557-561$.

Jeeva, S. (2009). Horticultural potential of wild edible fruits used by the Khasi tribes of Meghalaya. J. Hortic. For. 1, 182-192.

Jeyaprakash, K., Ayyanar, M., Geetha, K. N., and Sekar, T. (2011). Traditional uses of medicinal plants among the tribal people in Theni district (Western Ghats), Southern India. Asian Pac. J. Trop. Biomed. 1, S20-S25. doi: 10.1016/S2221-1691(11)60115-9

Jones, A. D. (2017). Critical review of the emerging research evidence on agricultural biodiversity, diet diversity, and nutritional status in low- and middle-income countries. Nutr. Rev. 75, 769-782 doi: 10.1093/nutrit/nux040

Kar, A. (2004). Common wild vegetables of Aka tribe of Arunachal Pradesh. Indian J. Trad. Know. 3, 305-313

Kar, A., and Borthakur, S. K. (2007). Wild vegetables sold in local markets of Karbi Anglong, Assam. Indian J. Tradit. Know. 6, 169-172

Kar, A., and Borthakur, S. K. (2008). Wild vegetables of Karbi-anglong district, Assam. Nat. Prod. Rad. 7, 448-460

Katewa, S. S., Chaudhary, B. L., Jain, A., and Galav, P. (2003). Traditional uses of plant biodiversity from Aravalli hills of Rajasthan. Indian J. Tradit. Knowl. 2, 27-39

Katz, E., Lopez, C. L., Fleury, M., Miller, R. P., Payê V., Dias, T., et al. (2012). No greens in the forest? Note on the limited consumption of greens in the Amazon. Acta Soc. Bot. Pol. 81, 283-293 doi: 10.5586/asbp.2012.048

Khan, T. M., and Kakde, U. B. (2014). Biodiversity in wild vegetables of Konkan region - Maharashtra. Int. J. Res. Biosci. Agric. Technol. 2, 226-240.
Khaund, P., and Joshi, S. R. (2013). Wild edible macrofungal species consumed by the Khasi tribe of Meghalaya, India. Indian J. Nat. Prod. Res. 4, 197-204.

Konsam, S., Thongam, B., and Handique, A. K. (2016). Assessment of wild leafy vegetables traditionally consumed by the ethnic communities of Manipur, northeast India. J. Ethnobiol. Ethnomed. 12:9. doi: 10.1186/s13002-016-0083-1

Kumar, A. (2013). Ethnobotanical study of wild vegetables used by rural communities of Kannauj district, Uttar Pradesh, India. Emir. J. Food Agric. 24, 760-766. doi: 10.9755/ejfa.v25i10.16403

Kumar, P. G. M., and Shiddamallayya, N. (2014). Documentation of wild plant tubers as food resources in Hassan district, Karnataka. Int. J. Appl. Biol. Pharm. Technol. 5, 90-95

Kumar, V., and Jain, S. K. (2002). Plant products in some tribal markets of central India. Econ. Bot. 56, 242-245. doi: 10.1663/00130001(2002)056[0242:PPISTM]2.0.CO;2

Labadarios, D. (2005). Malnutrition in the developing world: the triple burden. South Afr. J. Clin. Nutr. 18, 119-121. doi: 10.1080/16070658.2005.11734052

Leonti, M., Nebel, S., Rivera, D., and Heinrich, M. (2006). Wild gathered food plants in the European Mediterranean: a comparative analysis. Econ. Bot. 60, 130-142. doi: 10.1663/0013-0001(2006)60[130:WGFPIT]2.0.CO;2

Leonti, M., Ramirez, R., Sticher, F., and Heinrich, O. M. (2003). Medicinal flora of the Popoluca, México: a botanico-systematical perspective. Econ. Bot. 57, 218-230. doi: 10.1663/0013-0001(2003)057[0218:MFOTPM]2.0.CO;2

Loh, J., and Harmon, D. (2005). A global index of biocultural diversity. Ecol. Indicat. 5, 231-241 doi: 10.1016/j.ecolind.2005.02.005

Luczaj, L. (2008). Archival data on wild food plants eaten in Poland in 1948. J. Ethnobiol. Ethnomed. 4:4. doi: 10.1186/1746-4269-4-4

Luczaj, L. (2012). Ethnobotanical review of wild edible plants of Slovakia. Acta Soc. Bot. Pol. 81, 245-255. doi: 10.5586/asbp.2012.030

Lykke, A. M., Mertz, O., and Ganaba, S. (2002). Food consumption in rural Burkina Faso. Ecol. Food Nutr. 41, 119-153. doi: 10.1080/03670240214492

Maffi, L., and Woodley, E. (2012). Biocultural Diversity Conservation: A Global Sourcebook. London; Washington, DC: Routledge. doi: 10.4324/9781849774697

Mahadkar, S., Valvi, S., and Rathod, V. (2012). Nutritional assessment of some selected wild edible plants as a good source of mineral. Asian J. Plant Sci. Res. $2,468-472$.

Mahapatra, A. K., and Panda, P. C. (2012). Wild edible fruit diversity and its significance in the livelihood of indigenous tribals: evidence from eastern India. Food Secur. 4, 219-234. doi: 10.1007/s12571-012-0186-z

Maikhuri, R. K., Semwal, D. L., Singh, A., and Nautiyal, D. C. (1994). Wild fruits as a contribution to sustainable rural development: a case study from the Garhwal Himalaya. Int. J. Sustain. Dev. World Ecol. 1, 56-68. doi: $10.1080 / 13504509409469861$

Mani, M. S. (1974). "Biogeographical evolution in India," in Ecology and Biogeography in India, ed M. S. Mani (Dordrecht: Springer), 698-724. doi: 10.1007/978-94-010-2331-3_24

Mao, A. A., Hynniewta, T. M., and Sanjappa, M. (2009). Plant wealth of Northeast India with reference to ethnobotany. Indian J. Tradit. Know. 8, 96-103.

Mazhar, F., Buckles, D., Satheesh, P. V., and Akhter, F. (2007). Food Sovereignty and Uncultivated Biodiversity in South Asia. New Delhi, India: Academic Foundation.

Medhi, P., and Borthakur, S. K. (2012). Phytoresources from North Cachar hills of Assam, India-VII: semi-domesticated and protected plants. Pleione 6, 66-79.

Medhi, P., Sarma, A., and Borthakur, S. K. (2014). Wild edible plants from the Dima Hasao district of Assam, India. Pleione 8, 133-148.

Melamed, Y., Kislev, M. E., Geffen, E., Lev-Yadun, S., and Goren-Inbar, N. (2016). The plant component of an acheulian diet at Gesher Benot Ya'aqov, Israel. Proc. Natl. Acad. Sci. U.S.A. 113, 14674-14679. doi: 10.1073/pnas.16078 72113

Mishra, M., and Shrivastava, M. (2015). Trade of minor forest products in the rural markets of central India. Biol. Forum 7, 516-521.

Mishra, M. L., Sood, S., and Shukla, U. N. (2018). Phyto-nutritional and mineral composition of Indian horse chestnut (Aesculus indica) seeds. J. Pharm. Phytochem. 7, 2159-2162. doi: 10.20546/ijcmas.2018.709.270

Mishra, N., Panda, T., Pradhan, B. K., Rout, S. D., Mohanty, R. B., Kishor, A., et al. (2016). Indigenous knowledge in utilization of wetland plants of Bhadrak district, Odisha, India. Indian J. Nat. Prod. Resour. 7, 82-89.

Mishra, S., Sharma, S., and Vasudevan, P. (2015). "Role of edible food plants in women's nutrition and health," in Women, Technology and Development, eds P. 
Vasudevan, S. Sharma, V. P. Sharma and M. Verma (Narosa Publishing House), 1-17.

Misra, R. C., Sahoo, H. K., Pani, D. R., and Bhandari, D. C. (2013). Genetic resources of wild tuberous food plants traditionally used in Similipal biosphere reserve, Odisha, India. Genet. Resour. Crop Evol. 60, 2033-2054. doi: 10.1007/s10722-013-9971-6

Misra, S., Maikhuri, R. K., Kala, C. P., Rao, K. S., and Saxena, K. G. (2008). Wild leafy vegetables: a study of their subsistence dietetic support to the inhabitants of Nanda Devi biosphere reserve, India. J. Ethnobiol. Ethnomed. 4:15. doi: 10.1186/1746-4269-4-15

Moerman, D. E. (1996). An analysis of the food plants and drug plants of native North America. J. Ethnopharmacol. 52, 1-22. doi: 10.1016/0378-8741(96)01393-1

Mohammed, S., Kasera, P. K., and Shukla, J. K. (2004). Unexploited plants of potential medicinal value from the Indian Thar desert. Nat. Prod. Rad. 3, 69-74.

Mohan, V. R., and Kalidass, C. (2010). Nutritional and antinutritional evaluation of some unconventional wild edible plants. Trop. Subtrop. Agroecosyst. $12,495-506$.

Mukherjee, S., and Chaturvedi, S. S. (2016). "Uitilization of wild edible trees in fringe area of Neora-valley national park, Darjeeling," in International Conference on Agriculture, Food Science, Natural Resource Management and Environmental Dynamics: The Technology, People and Sustainable Development. (Mohanpur, Nadia, West Bengal, India).

Murugan, M., Raj, X. J., Kumar, G. P., Sunil, G., and Singh, S. B. (2010). Phytofoods of Nubra valley, Ladakh-the cold desert. Indian J. Tradit. Know. 9, 303-308.

Nair, R., and Agrawal, V. (2017). Nutritive values and uses of some important arid zone fruit trees of Madhya Pradesh. Int. J. Chem. Stud. 5, 399-404.

Namsa, N. D., Mandal, M., Tangjang, S., and Mandal, S. C. (2011). Ethnobotany of the Monpa ethnic group at Arunachal Pradesh, India. J. Ethnobiol. Ethnomed. 7:31. doi: 10.1186/1746-4269-7-31

Narayanan, M. R., Anilkumar, N., Balakrishnan, V., Sivadasan, M., Alfarhan, H. A., and Alatar, A. A. (2011). Wild edible plants used by the Kattunaikka, Paniya and Kuruma tribes of Wayanad district, Kerala, India. J. Med. Plants Res. 5, $3520-3529$.

Nath, A., and Maiti, G. G. (2011). An ethnobotancial report on less-known leafy vegetables consumed by different communities of Barak valley, Assam, India. Ecobios 4, 45-55.

Nayar, M. P. (1996). Hotspots of Endemic Plants of India, Nepal and Bhutan. Trivandrum: Tropical Botanic Garden and Research Institute.

Nazarudeen, A. (2010). Nutritional composition of some lesser-known fruits used by the ethnic communities and local folks of Kerala. Indian J. Tradit. Know. 9, $398-402$

Neogi, B., Prasad, M. N., and Rao, R. R. (1989). Ethnobotany of some weeds of Khasi and Garo hills, Meghalaya, Northeastern India. Econ. Bot. 43, 471-479. doi: 10.1007/BF02935921

Nongdam, P., and Tikendra, L. (2014). The nutritional facts of bamboo shoots and their usage as important traditional foods of northeast India. Int. Sch. Res. Notices 2014:679073. doi: 10.1155/2014/679073

Ogle, B. M. (2001). Wild Vegetables and Micronutrient Nutrition: Studies on the Significance of Wild Vegetables in Women's Diets in Vietnam. (Doctoral dissertation, Acta Universitatis Upsaliensis).

Ogle, B. M., and Grivetti, L. E. (1985a). Legacy of the chameleon: edible wild plants in the kindom of Swaziland, Southern Africa. A cultural, ecological, nutritional study. part II - demographics, species availability and dietary use, analysis by ecological zone. Ecol. Food Nutr. 17, 1-30. doi: 10.1080/03670244.1985.99 90879

Ogle, B. M., and Grivetti, L. E. (1985b). Legacy of the chameleon: edible wild plants in the kingdom of Swaziland, Southern Africa. A cultural, ecological, nutritional study. part IV-nutritional analysis and conclusions. Ecol. Food Nutr. 17, 41-64. doi: 10.1080/03670244.1985.9990881

Ogle, B. M., Tuyet, H. T., Duyet, H. N., and Dung, N. N. X. (2003). Food, feed or medicine: the multiple functions of edible wild plants in Vietnam. Econ. Bot. 57, 103-117. doi: 10.1663/0013-0001(2003)057[0103:FFOMTM]2.0.CO;2

Padalia, K. (2015). Gewai saag: a folk medicine used by the tribal people of Central Himalayan region. Indian J. Trad. Know. 1, 144-146.

Padoch, C., and Sunderland, T. (2014). Managing landscapes for food security and enhanced livelihoods: building upon a wealth of local experience. Unasylva 64:2013/2.
Panda, T. (2014). Traditional knowledge on wild edible plants as livelihood food in Odisha, India. J. Biol. Earth Sci. 4, B144-B159

Pandey, A., Singh, S., Singh, R., and Mavinkurve, R. G. (2015). Use of indigenous plants in traditional health care systems and economic use by Mishing tribe of Jorhat, Assam, India. World J. Pharm. Sci. 4, 1277-1289.

Pandey, A. K., and Bora, H. R. (1997). Edible plants of Shan tribe of Assam. Anc. Sci. Life 16, 258-276

Pandey, G. (1998). Wild temperate fruit plants of Himachal Pradesh, India. Plant Genet. Resour. Newslett. 116, 9-11.

Pandey, K. C., and Pande, N. (2016). Ethnobotanical documentation of wild edible plants used by Gujjar community of Tarai West forest division Ramnagar, Nainital, India. Curr. World Environ. 11, 808-818 doi: 10.12944/CWE.11.3.16

Pandey, R. K., and Saini, S. K. (2007). Edible plants of tropical forests among tribal communities of Madhya Pradesh. Indian J. Tradit. Know. 6, 185-190

Pant, S., and Samant, S. S. (2010). Ethnobotanical observations in the Mornaula reserve forest of Komoun, West Himalaya, India. Ethnobot. Leaflets 14, 193-217

Pardo-de-Santayana, M., Tardío, J., Blanco, E., Carvalho, A. M., Lastra, J. J., San Miguel, E., et al. (2007). Traditional knowledge of wild edible plants used in the northwest of the Iberian Peninsula (Spain and Portugal): a comparative study. J. Ethnobiol. Ethnomed. 3:27. doi: 10.1186/1746-4269-3-27

Parinitha, M., Harish, G. U., Vivek, N. C., Mahesh, T., and Shivanna, M. B. (2004). Ethno-botanical wealth of Bhadra wild life sanctuary in Karnataka. Indian J. Tradit. Know. 3, 37-50

Parisara, N., and Kiran, B. R. (2016). Enumeration of leafy vegetables of BhadravathiTaluk, Karnataka. Int. J. Sci. Res. Sci. Technol. 2, 32-35.

Patiri, B., and Borah, A. (2007). Wild Edible Plants of Assam. Guwahati: Geetakhi Printers and Publishers.

Paumgarten, F., and Shackleton, C. M. (2011). The role of non-timber forest products in house- hold coping strategies in South Africa: the influence of household wealth and gender. Popul. Environ. 33, 108-131. doi: 10.1007/s11111-011-0137-1

Pemberton, R. W., and Lee, N. S. (1996). Wild food plants in South Korea; market presence, new crops, and exports to the United States. Econ. Bot. 50, 57-70. doi: $10.1007 / \mathrm{BF} 02862113$

Phoze, N. L., Kumar, Y., and Myrboh, B. (2001). Survey and assessment of floral diversity on wild edible plants from Senapati district of Manipur, Northeast India. J. Biodiv. Environ. Sci. 1, 50-62.

Pingali, P. (2015). Agricultural policy and nutrition outcomes - getting beyond the pre-occupation with staple grains. Food Secur. 7, 583-591. doi: 10.1007/s12571-015-0461-x

Pinstrup-Andersen, P. (2007). Agricultural research and policy for better health and nutrition in developing countries: a food systems approach. Agric. Econ. 37, 187-198. doi: 10.1111/j.1574-0862.2007. 00244.x

Powell, B., Thilsted, S., Ickowitz, A., Termote, C., Sunderland, T., and Herforth, A. (2015). Improving diets with wild and cultivated biodiversity from across the landscape. Food Secur. 7, 535-554. doi: 10.1007/s12571-0150466-5

Pradhan, B. K., and Badola, H. K. (2008). Ethnomedicinal plant use by Lepcha tribe of Dzongu valley, bordering Khangchendzonga biosphere reserve, in north Sikkim, India. J. Ethnobiol. Ethnomed. 4:22. doi: 10.1186/1746-42 69-4-22

Pretty, J. N. (1995). Regenerating Agriculture: Policies and Practice for Sustainability and self-reliance. Regenerating agriculture: policies and Practice for Sustainability and Self-reliance. London: Earthscan Publications; Washington, DC: National Academy Press; Bangalore: ActionAid and Vikas.

Price, L. L. (2006). "Wild food plants in farming environments with special reference to Northeastern Thailand, food as functional and medicinal, and the social roles of women," in Eating and Healing: Traditional Food as Medicine, eds A. Pieroni and L. L. Price (New York; London; Oxford: Food Products Press), 65-100.

Pugalenthi, M., Vadivel, V., Gurumoorthi, P., and Janardhanan, K. (2004). Comparative nutritional evaluation of little known legumes, Tamarindus indica, Erythrina indica and Sesbania bispinosa. Trop. Subtrop. Agroecosyst. 4, 107-123.

Radha, B., Singh, R. D., Tiwari, J. K., Tiwari, P., and Gairola, A. (2013). Wild edible plant resources of the Lohba range of Kedarnath forest division (KFD), Garhwal Himalaya, India. Int. Res. J. Biol. Sci. 2, 65-73. 
Rajasab, A. H., and Isaq, M. (2004). Documentation of folk knowledge on edible wild plants of North Karnataka. Indian J. Tradit. Know. 3, 419-429.

Rajyalakshmi, P., Venkatalaxmi, K., Venkatalakshmamma, K., Jyothsna, Y., Devi, K. B., and Suneetha, V. (2001). Total carotenoid and beta-carotene contents of forest green leafy vegetables consumed by tribals of south India. Plant Foods Hum. Nutr. 56, 225-238. doi: 10.1023/A:1011125232097

Ramachandran, V. S. (2007). Wild edible plants of the Anamalais, Coimbatore district, western Ghats, Tamil Nadu. Indian J. Tradit. Know. 6, 173-176

Ramachandran, V. S., Joseph, S., and Aruna, R. (2009). Ethnobotanical studies from Amaravathy range of Indira Gandhi wildlife sanctuary, Western Ghats, Coimbatore District, Southern India. Ethnobot. Leaflets 13, 1069-1087.

Rana, J. C., Pradheep, K., Chaurasia, O. P., Sood, S., Sharma, R. M., Singh, A., et al. (2012). Genetic resources of wild edible plants and their uses among tribal communities of cold arid region of India. Genet. Resour. Crop Evol. 59, 135-149. doi: 10.1007/s10722-011-9765-7

Ranfa, A., Maurizi, A., Romano, B., and Bodesmo, M. (2014). The importance of traditional uses and nutraceutical aspects of some edible wild plants in human nutrition: the case of Umbria (central Italy). Plant Biosyst. 148, 297-306. doi: 10.1080/11263504.2013.770805

Rasingam, L. (2012). Ethnobotanical studies on the wild edible plants of Irula tribes of Pillur valley, Coimbatore district, Tamil Nadu, India. Asian Pac. J. Trop. Biomed. 2, S1493-S1497. doi: 10.1016/S2221-1691(12)60443-2

Rathore, M. (2009). Nutrient content of important fruit trees from arid zone of Rajasthan. J. Hortic. For. 1, 103-108.

Rowland, D., Ickowitz, A., Powell, B., Nasi, R., and Sunderland, T. C. H. (2016). Forest foods and healthy diets: quantifying the contributions. Environ. Conserv. 44, 102-114. doi: 10.1017/S0376892916000151

Royal Society (2009). Reaping the Benefits: Science and the Sustainable Intensification of Global Agriculture. London: The Royal Society.

Samydurai, P., Thangapandian, V., and Aravinthan, V. (2012). Wild habits of Kolli hills being staple food of inhabitant tribes of Eastern Ghats, Tamil Nadu, India. Indian J. Nat. Prod. Resour. 3, 432-437

Sarvalingam, A., Rajendran, A., and Sivalingam, R. (2015). Wild edible plant resources used by the Irulas of the Maruthamalai Hills, Southern Western Ghats, Coimbatore, Tamil Nadu. Indian J. Nat. Prod. Resour. 5, 198-201.

Sasi, R., and Rajendran, A. (2012). Diversity of wild fruits in Nilgiri hills of the Southern Western Ghats: ethnobotanical aspects. Int. J. Appl. Biol. Pharm. Technol. 3, 82-87.

Sasi, R., Rajendran, A., and Maharajan, M. (2011). Wild edible plant diversity of Kotagiri hills - a part of Nilgiri biosphere reserve, Southern India. J. Res. Biol. 2, 80-87.

Sathyavathi, R., and Janardhanan, K. (2014). Wild edible fruits used by Badagas of Nilgiri district, Western Ghats, Tamilnadu, India. J. Med. Plants Res. 8, 128-132. doi: 10.5897/JMPR11.445

Satter, M. M. A., Khan, M. M. R. L., Jabin, S. A., Abedin, N., Islam, M. F., and Shaha, B. (2016). Nutritional quality and safety aspects of wild vegetables consume in Bangladesh. Asian Pac. J. Trop. Biomed. 6, 125-131. doi: 10.1016/j.apjtb.2015.11.004

Satyavani, S., Satyavathi, K., and Padal, S. D. (2015). Wild edible plants used for indigenous community of North-Coastal Andhra Pradesh, India. BMR Phytomed. 2, 1-7

Scoones, I., Melnyk, M., and Pretty, J. N. (1992). The Hidden Harvest: Wild Foods in Agricultural Systems. A Bibliography and Literature Review. London: International Institute for Environment and Development.

Sheela, K., Nath, K. G., Vijayalakshmi, D., Yankanchi, G. M., and Patil, R. B. (2004). Proximate composition of underutilized green leafy vegetables in Southern Karnataka. J. Hum. Ecol. 15, 227-229. doi: 10.1080/09709274.2004. 11905698

Shin, T., Fujikawa, K., Moe, A. Z., and Uchiyama, H. (2018). Traditional knowledge of wild edible plants with special emphasis on medicinal uses in Southern Shan State, Myanmar. J. Ethnobiol. Ethnomed. 14:48. doi: 10.1186/s13002-018-0248-1

Simopoulos, A. P. (2004). Omega-3 fatty acids and antioxidants in edible wild plants. Biol. Res. 37, 263-277. doi: 10.4067/S0716-97602004000200013

Singh, A., Satanker, N., Kushwaha, M., Disoriya, R., and Gupta, A. K. (2013). Ethno-botany and uses of non-graminaceous forage species of
Chitrakoot region of Madhya Pradesh. Indian J. Nat. Prod. Resour. 4, 425-431.

Singh, B. K., Pathak, K. A., and Ramakrishna, Y. (2013). Underutilized Vegetable Crops and Spices of Mizoram: Needs Exploration and Utilization. Developing the Potential of Underutilized Horticultural Crops of Hill Regions. New Delhi: Today \& Tomorrow's Printers and Publishers. 217-232.

Singh, H. B., and Arora, R. K. (1978). Wild edible plants of India. New Delhi: ICAR.

Singh, J., Rajasekaran, A., Negi, A. K., and Pala, N. A. (2014). Wild vegetable plants used by tribal people of Kinnaur district, Himachal Pradesh, India. Int. J. Usufructs Manage. 15, 47-56.

Singh, V. N., Chanu, L. I., and Baruah, M. K. (2011). An ethnobotanical study of Chirus-A less known tribe of Assam. Indian J. Tradit. Know. 10, 572-574.

Sinha, R., and Lakra, V. (2005). Wild tribal food plants of Orissa. Indian J. Tradit. Know. 4, 246-252

Sinha, R., and Lakra, V. (2007). Edible weeds of tribals of Jharkhand, Orissa and West Bengal. Indian J. Tradit. Know. 6, 217-222

Srivastava, T. N. (1998). Wild edible plants of Jammu \& Kashmir state-an ethnobotanical study. Anc. Sci. Life. 7:201.

Sujarwo, W., Arinasa, I. B. K., Caneva, G., and Guarrera, P. M. (2014). Traditional knowledge of wild and semi-wild edible plants used in Bali (Indonesia) to maintain biological and cultural diversity, Plant Biosyst. 150, 971-976 doi: 10.1080/11263504.2014.994577

Sundriyal, M., and Sundriyal, D. C. (2001). Wild edible plants of the Sikkim himalaya: nutritive values of selected species. Econ. Bot. 55, 377-390 doi: 10.1007/BF02866561

Sundriyal, M., and Sundriyal, R. C. (2003). Underutilized edible plants of the Sikkim himalaya: need for domestication. Curr. Sci. 25, 731-736.

Suthari, S., Sreeramulu, N., Omkar, K., and Raju, V. S. (2014). The climbing plants of northern Telangana in India and their ethnomedicinal and economic uses. Indian J. Plant Sci. 3, 86-100.

Swarnkar, S., and Katewa, S. S. (2008). Ethnobotanical observation on tuberous plants from tribal area of Rajasthan (India). Ethnobot. Leaflets 12, 647-666. doi: 10.17348/era.12.0.211-235

Tardío, J., Pardo-de-Santayana, M., and Morales, R. (2006). Ethnobotanical review of wild edible plants in Spain. Bot. J. Lin. Soc. 152, 27-71. doi: 10.1111/j.1095-8339.2006.00549.x

The Plant List (2010). Version 1. Published on the Internet. Available online at: http://www.theplantlist.org/ (accessed January 1)

Thomas, M., Sahu, P., Shrivastava, A., and Hussain, Z. (2011). Biodiversity and livelihood options of people in Chambal ravine of Morena district, Madhya Pradesh, India. J. Trop. For. 27, 40-56.

Tiwari, J. K., Ballabha, R., and Tiwari, P. (2010). Some promising wild edible plants of Srinagar and its adjacent area in Alaknanda valley of Garhwal Himalaya, India. J. Am. Sci. 6, 167-174.

Turner, N. J., Luczaj, L., Migliorini, P., Pieroni, A., Dreon, A. L., Enrica, L., et al. (2011). Edible and tended wild plants, traditional ecological knowledge and agroecology. Crit. Rev. Plant Sci. 30, 198-225. doi: 10.1080/07352689.2011.554492

Upreti, K., Tewari, L. M., Pangtey, Y. P., and Jalal, J. S. (2010). "Diversity and distribution of wild edible fruit plants of Uttarakhand," in Nainital Biodiversity Potentials of the Himalaya eds L. M. Tewari, Y. P. S. Pangtey, G. Tewari (Gyanodaya Prakashan, Nainital), 157-196.

Uusiku, N. P., Oelofse, A., Duodu, K. G., Bester, M. J., and Faber, M. (2010). Nutritional value of leafy vegetables of sub-Saharan Africa and their potential contribution to human health: a review. J. Food Composit. Anal. 23, 499-509. doi: 10.1016/j.jfca.2010. 05.002

Vikneshwaran, D., Viji, M., and Lakshmi, K. R. (2008). A survey of the ethnomedicinal flora of the Sirumalai hills, Dindugul district, India. Ethnobot. Leaflets 12, 948-953.

Vishwakarma, K. L., and Dubey, V. (2011). Nutritional analysis of wild edible herbs used in eastern Chhattisgarh, India. Emir. J. Food Agric. 15, 554-560.

Von Grebmer, K. A., Saltzman, E., Birol, D., Wiesmann, N., Prasai, S., Yin, Y., et al. (2014). 2014 Global Hunger Index: the Challenge of Hidden Hunger. Washington, DC; Dublin: Welthungerhilfe, International Food Policy Research Institute, and Concern Worldwide, Bonn. 
Wills, R. B., Lim, J. S., Greenfield, H., and Bayliss-Smith, T. (1983). Nutrient composition of taro (Colocasia esculenta) cultivars from the Papua New Guinea highlands. J. Sci. Food Agric. 34, 1137-1142. doi: 10.1002/jsfa.27403 41015

World Food Summit (1996). Rome Declaration on World Food Security. Rome.

World Health Organization (2008). Indicators for Assessing Infant and Young Child Feeding Practices: Part 1 Definitions. Switzerland: Geneva.

Wunder, S., Börner, J., Shively, G., and Wyman, M. (2014). Safety nets, gap filling and forests: a global-comparative perspective. World Dev. 64(Suppl. 1): S29-S42. doi: 10.1016/j.worlddev.2014. 03.005

Yakang, B., Gajurel, P. R., Potsangbam, S., and Bhuyan, L. R. (2013). Account of common and traditional non-timber forest products used by Apatani tribe of Arunachal Pradesh, India. Pleione 7, 514-529.

Yuhlung, C. C., and Bhattacharyya, M. (2014). Practice of ethno-medicine among the Chothe tribe of Manipur, North-East India. Int. J. Pharm. Biol. Arch. 5, 138-149.
Yumnam, J. Y., Bhuyan, S. I., Khan, M. L., and Tripathi, O. P. (2011). Agrodiversity of East Siang-Arunachal Pradesh, Eastern Himalaya. Asian J. Agric. Sci. 3, 317-326.

Zhang, Y., Lu, X., Zeng, S., Huang, X., Guo, Z., Zheng, Y., et al. (2015). Nutritional composition, physiological functions and processing of lotus (Nelumbo nucifera Gaertn.) seeds: a review. Phytochem. Rev. 14, 321-334. doi: 10.1007/s11101-015-9401-9

Conflict of Interest: The authors declare that the research was conducted in the absence of any commercial or financial relationships that could be construed as a potential conflict of interest.

Copyright (c) 2020 Ray, Ray and Sreevidya. This is an open-access article distributed under the terms of the Creative Commons Attribution License (CC BY). The use, distribution or reproduction in other forums is permitted, provided the original author(s) and the copyright owner(s) are credited and that the original publication in this journal is cited, in accordance with accepted academic practice. No use, distribution or reproduction is permitted which does not comply with these terms. 